UNIVERSIDADE DE SÃO PAULO FFCLRP - DEPARTAMENTO DE PSICOLOGIA PROGRAMA DE PÓS-GRADUAÇÃO EM PSICOBIOLOGIA

\title{
FORMAÇÃO CONTINUADA PARA PROFESSORES E O USO DE VÍDEOS- RELATOS: CONSTRUÇÃO E AVALIAÇÃO DE UMA INTERVENÇÃO
}

\author{
Monara Nelid Fortuna Vieira
}

Dissertação apresentada à Faculdade de Filosofia, Ciências e Letras de Ribeirão Preto da Universidade de São Paulo, como parte das exigências para obtenção do título de Mestra em Ciências. Área: Psicobiologia

Ribeirão Preto - SP

2019 
UNIVERSIDADE DE SÃO PAULO FFCLRP - DEPARTAMENTO DE PSICOLOGIA PROGRAMA DE PÓS-GRADUAÇÃO EM PSICOBIOLOGIA

MONARA NELID FORTUNA VIEIRA

FORMAÇÃO CONTINUADA DE PROFESSORES E O USO DE VÍDEOS-RELATOS: CONSTRUÇÃO E AVALIAÇÃO DE UMA INTERVENÇÃO

\author{
Versão Corrigida
}

Dissertação apresentada à Faculdade de Filosofia, Ciências e Letras de Ribeirão Preto da Universidade de São Paulo, como parte das exigências para obtenção do título de Mestre (a) em Ciências, obtido no Programa de PósGraduação em Psicobiologia

Orientadora: Profa. Dra. Fabiana Maris Versuti

Coorientadora: Profa. Dra. Patrícia Ferreira Monticelli 
Autorizo a reprodução total ou parcial deste trabalho por qualquer meio convencional ou eletrônico, para fins de estudo e pesquisa, desde que citada a fonte.

Vieira, Monara N. F.

Formação continuada de professores e o uso de vídeos-relatos: construção e avaliação de uma intervenção. Ribeirão Preto, 2019. $71 \mathrm{p}$.

Dissertação de Mestrado Faculdade de Filosofia Ciências e Letras de Ribeirão Preto - USP. Área de concentração: Psicobiologia.

Orientadora: Versuti, Fabiana Maris;

Co-orientadora: Monticelli, Patrícia Ferreira

1. Formação de professores. 2. Percepção docente. 3. Dificuldades de aprendizagem. 4. TDIC 


\section{FOLHA DE APROVAÇÃO}

\section{Monara Nelid Fortuna Vieira}

Formação continuada de professores e o uso de vídeos-relatos: construção e avaliação de uma intervenção

Dissertação apresentada ao Programa de Pós- Graduação em Psicobiologia da Faculdade de Filosofia, Ciências e Letras de Ribeirão Preto - USP como parte dos requisitos para obtenção do grau de Mestre em Ciências. Área de concentração: Psicobiologia.

Orientadora: Fabiana Maris Versuti

Co-orientadora: Monticelli, Patrícia Ferreira

Aprovado em:

Banca Examinadora

Prof. Dr.

Instituição: Assinatura:

Prof. Dr.

Instituição: Assinatura:

Prof. Dr.

Instituição: Assinatura: 
DEDICATÓRIA

Dedico esse trabalho ao meu marido Guilherme, que sempre acreditou em mim e me apoiou em todos os momentos; e à minha filha Marina, que com seu sorriso de cada manhã foi fonte de energia para seguir em frente. 


\section{AGRADECIMENTOS}

\section{Agradeço}

À agência financiadora CAPES, pelo reconhecimento e o apoio dado a esta pesquisa;

Às colegas e profissionais, Natália e Raquel, que contribuíram na aplicação da intervenção, e que com muito respeito ao trabalho, realizaram as atividades brilhantemente;

Ao André, que com muita dedicação, contribuiu na construção dos vídeos;

Às professoras Fabiana e Patrícia, que me deram voto de confiança e esperança, que me estenderam a mão quando iniciei a trajetória da maternidade e que foram pilares para eu chegar até aqui;

À amiga que a vida me presenteou, Mayra. A luz que a acompanha me guiou a todo momento por meio de seus conselhos, afeto e compartilhamento de conhecimento. 


\section{RESUMO}

Vieira, M. N. F. (2019). Formação continuada de professores e o uso de vídeos-relatos: construção e avaliação de uma intervenção. Dissertação de Mestrado, Programa de PósGraduação em Psicobiologia da Faculdade de Filosofia, Ciências e Letras de Ribeirão Preto, Universidade de São Paulo.

Evidências científicas apontam que o ambiente escolar influencia o processo de ensinoaprendizagem e que o professor pode ser elemento chave no desenvolvimento integral dos estudantes. Suas percepções e crenças acerca do comportamento humano, compõe o cenário educacional e afeta na aprendizagem. A formação docente é uma das variáveis que interferem neste fenômeno e suas lacunas nos objetivou a avaliar uma intervenção à luz da Psicobiologia como proposta de formação continuada. O estudo descreveu a construção de uma intervenção, com destaque para os casos reais por meio de vídeosrelatos, como constituinte de uma Tecnologia de Digital da Informação e Comunicação (TDIC) e avaliou o processo da intervenção a partir de um delineamento qualitativo das respostas dos professores ao longo do processo e quantitativo para verificação do efeito do processo na alteração de possíveis percepções deterministas em relação aos domínios do comportamento Dificuldades de aprendizagem e Doenças mentais. Evidencia-se que o processo gerou reflexão e incentivou observação mais cuidadosa dos professores em relação aos estudantes. Os professores puderam experimentar estratégias não utilizadas anteriormente e verificar seus efeitos em sala de aula. Foram encontradas percepções ligadas ao determinismo genético e estas não se modificaram ou aumentaram, mas as percepções que consideram o ambiente também aumentaram. Estes resultados foram estatisticamente significativos para Dificuldades de aprendizagem. Após a intervenção, mais professores relataram que ter um estudante com dificuldade de aprendizagem geneticamente influenciada afetaria muito ou completamente seu modo de instruí-lo e acompanhá-lo. De modo geral, a intervenção gerou resultados positivos sobre as percepções voltadas às influências ambientais e sobre a relevância das estratégias educacionais, além de proporcionar um itinerário formativo pautado em trocas de experiências, reflexões sobre a prática e aquisição de conhecimentos no âmbito da Psicobiologia relevantes à formação continuada de professores.

Palavras-chave: Formação de professores; Percepção docente; Dificuldades de aprendizagem; TDIC. 


\begin{abstract}
Vieira, M. N. F. (2019). Continous education of teachers and the use of video reports: building and evaluating an intervention. Dissertação de Mestrado, Programa de PósGraduação em Psicobiologia da Faculdade de Filosofia, Ciências e Letras de Ribeirão Preto, Universidade de São Paulo.
\end{abstract}

Scientific evidences indicate the school environment influences the teaching-learning process and that the teacher can be a key element in the whole development of the students. Their perceptions and believes about the human behavior make up the educational scenario and affect learning. The teacher's education is one of the variables that interfere in this phenomenom and its gaps pushed us to evaluate an intervention in the light of Psychobiology as a proposal for continous education. The study described the construction of an intervention, highlighting the real cases through video reports, as a component of a Digital Information and Communication Technology (TDIC) and evaluated the intervention process based on a qualitative outline of the responses of teachers throughout the process and quantitative to verify the effect of the process in changing possible deterministic perceptions regarding the domains of behavior Learning disabilities and Mental Diseases. It is evident that the process generated reflection and encouraged more careful observation of teachers in relation to students. Teachers were able to experiment with previously unused strategies and verify their effects in the classroom. Perceptions linked to genetic determinism have been found and have not changed or increased, but perceptions that consider the environment have also increased. These results were statistically significant for learning disabilities. After the intervention, more teachers reported that having a student with a genetically influenced learning disability would greatly or completely affect their way of instructing and accompanying them. In general, the intervention generated positive results on the perceptions of environmental influences and the relevance of educational strategies, as well as providing a formative itinerary based on exchange of experiences, reflections on the practice and acquisition of knowledge in Psychobiology relevant to continuing teacher education.

Keywords: Continous education of teachers; Teachers' perception; Learning disabilities; TDIC 


\section{LISTA DE TABELAS}

Tabela 1 - Porcentagem de percepção dos professores sobre as influências genéticas e ambientais nos domínios Dificuldades de aprendizagem e Doenças mentais na pré e pós intervenção, com indicação do possível efeito da intervenção pelo teste Qui quadrado $(n=52)$.

Tabela 2 - Porcentagem de percepção dos professores sobre seu método de instruir e acompanhar um estudante com dificuldade de aprendizagem geneticamente influenciada na pré e pós intervenção, com indicação do possível efeito da intervenção pelo teste Qui quadrado $(\mathrm{n}=52)$. 
FORMAÇÃO CONTINUADA PARA PROFESSORES E O USO DE VÍDEOSRELATOS: CONSTRUÇÃO E AVALIAÇÃO DE UMA INTERVENÇÃO ..........1

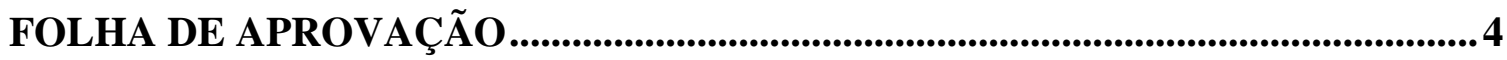

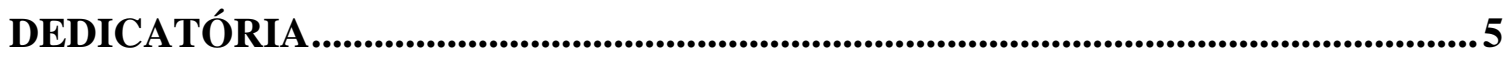

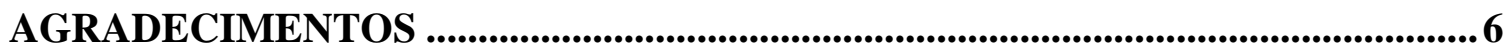

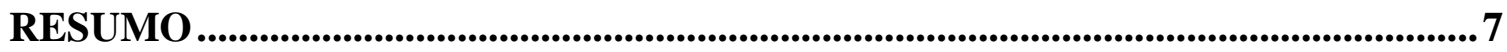

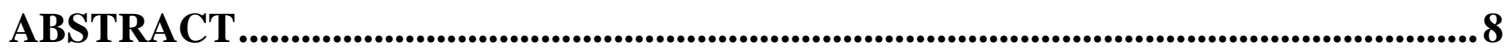

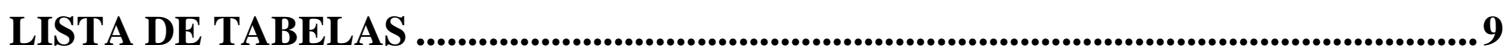

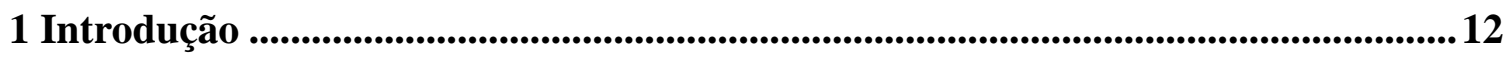

$1.1 \mathrm{O}$ ambiente escolar: papel da escola e do professor .............................................. 12

1.2 Contribuições da psicobiologia à formação continuada de professores................... 14

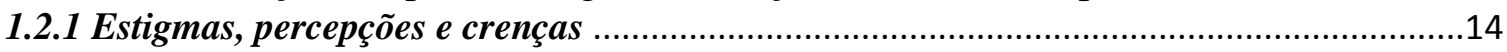

1.2.2 Influências sobre o comportamento humano: Genética x Ambiente ……........................16

1.3 Formação continuada de professores: lacunas e estratégias ................................... 17

1.3.1 Tecnologias Digitais da Informação e Comunicação (TDIC) e recursos educacionais....19

1.3.2 Uso de vídeos e seu potencial na mudança de percepções e comportamento .....................20

1.4 Domínios do comportamento relevantes no ambiente educacional ........................23

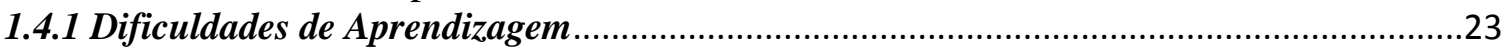

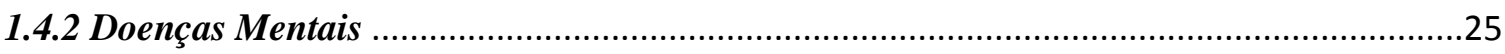

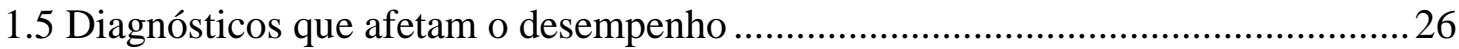

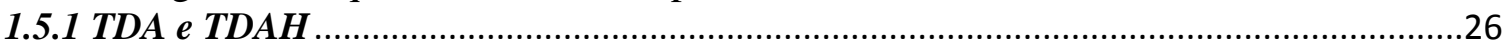

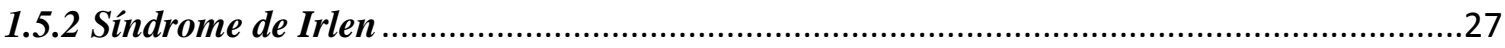

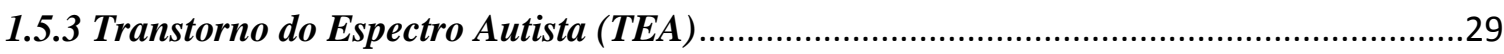

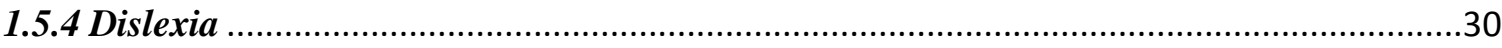

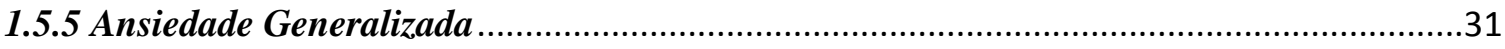

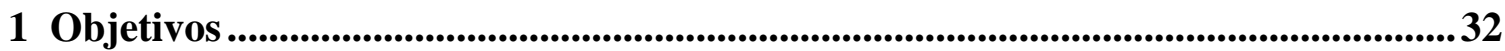

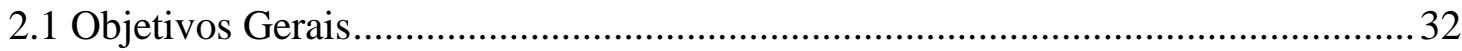

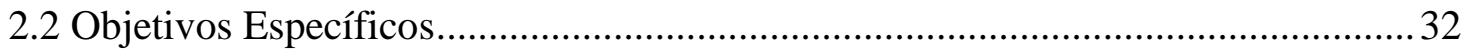

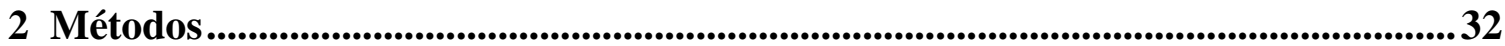

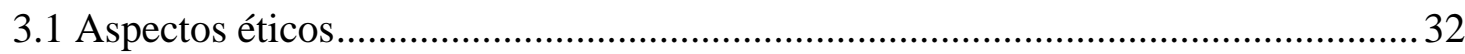




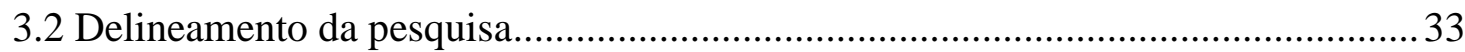

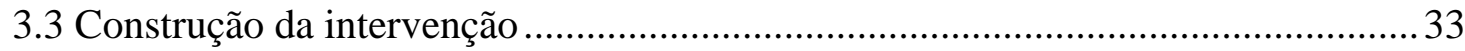

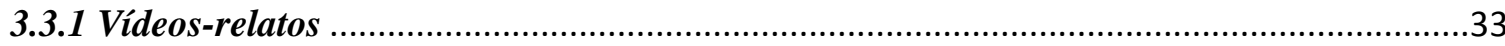

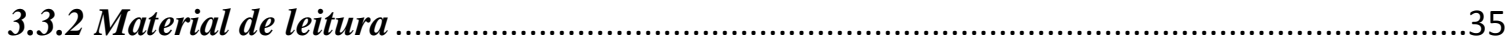

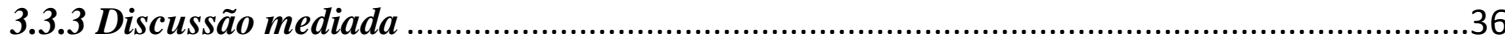

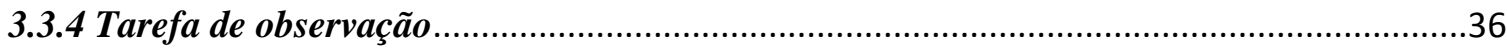

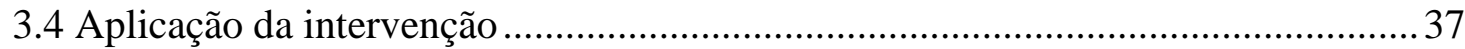

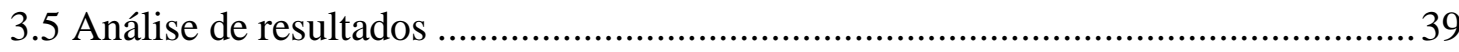

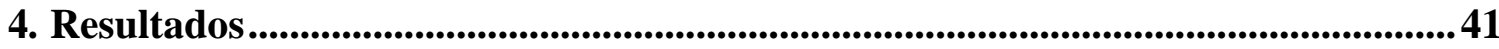

4.1 Respostas dos participantes às tarefas de observação e aplicação de estratégias ... 41

4.2. Resultados das percepções docentes sobre comportamentos relevantes no

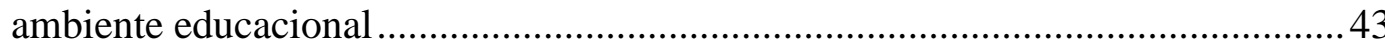

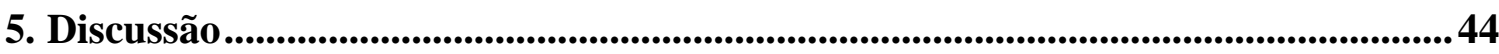

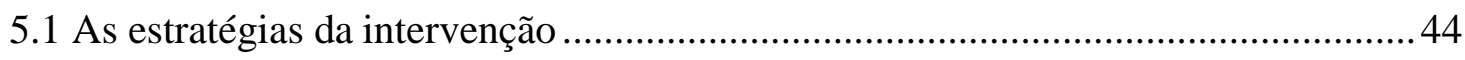

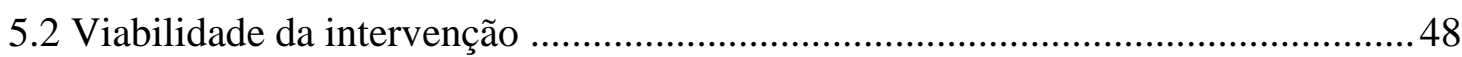

5.2.1 Relatos docentes e realização das atividades propostas na intervençãa o.............................48

5.2.2 Percepções docentes sobre comportamentos relevantes no ambiente educacional ............50

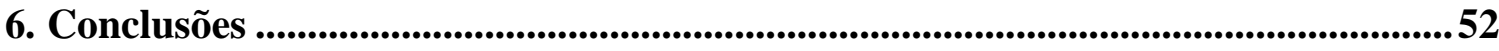

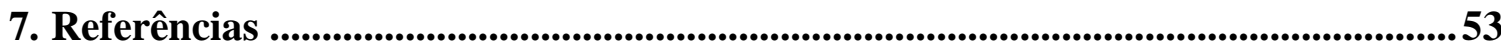

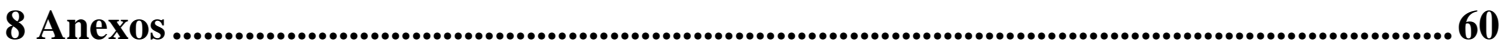

9. Apêndices .....................................................................................................................................................63 63

Apêndice A- Termo de Assentimento........................................................................63

Apêndice B - Termo de Consentimento (filmagens) ..............................................................65

Apêndice C- Termo de Consentimento (intervenção) ...................................................68

Apêndice D- Termo de armazenamento de dados ........................................................ 70

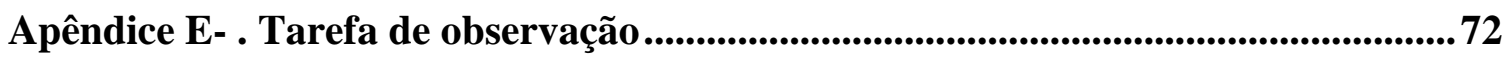




\section{Introdução}

\subsection{O ambiente escolar: papel da escola e do professor}

A escola na sociedade contemporânea assume duas funções, uma função de instruir relacionada ao acesso à informação, de transmissão de conhecimentos sócio-historicamente acumulado, e outra de educar relacionada com a possibilidade das pessoas de relacionar-se com o mundo e com a sociedade de maneira plena, autêntica e satisfatória. Tais funções não se excluem, mas se complementam, sendo o professor central neste processo (Gallo, 2013). O professor é a figura representativa deste processo, com função de contribuir na condução disso tudo. É elemento fundamental na escola e peça chave no processo de educar, é exemplo dentro de uma sala de aula e tem seu peso sobre o sucesso ou fracasso escolar do estudante. Ele coopera no desenvolvimento pessoal, social e profissional do indivíduo e forma pessoas pensantes e argumentativas, transmitindo o que sabe, transformando visões, gerando valores e fazendo mediações entre estudante e conhecimento (Bulgraen, 2010; Paula \& Faria, 2010; Sordi, 2005).

No papel de ensinar, ele pode professar saberes disciplinares ou transmitir conhecimento em contexto mais amplo, contando com suas experiências de vida e relacionando-as com o ambiente de ensino, sendo capaz de responder questões além dos conteúdos. Isso faz o professor ser membro insubstituível no processo de ensino, já que algumas coisas da vida são ensinadas somente de ser humano para ser humano (como a solidariedade, inclusão, gentileza), pois o ensinar se dá com crenças, experiências e emoções. Mas, para o professor ensinar, ele deve aprender a ensinar e renovar suas práticas pedagógicas, que não devem ser imutáveis diante das mudanças que nos acompanham, assim, cumprirá bem a função de formar cidadãos capacitados para a sociedade (Aquino, 2014; Bulgraen, 2010; Roldão, 2007).

Diante da referência que o professor é para nós, um simples gesto de sua parte pode exercer muita influência em nossa vida, por isso que, uma boa relação entre professor e estudante e boas ações docentes, são essenciais no desenvolvimento integral do estudante incluindo o aspecto cognitivo - portanto, a escola deve promover a troca e investir em estratégias que estreitem essa relação. No entanto, o estudante muitas vezes, considerado sujeito passivo do ensino, onde só recebe informação, deve ser colocado numa posição mais horizontal e levar em conta o que ele diz e o que ele quer aprender. A afetividade entre as pessoas e conteúdos proporciona um ambiente favorável à aprendizagem, com isso, torna-se relevante perceber o estudante como um ser completo, que tem seus potenciais, mas também suas emoções, pois quanto mais estável emocionalmente, mais preparado para aprender (Paula \& 
Formação Continuada De Professores E O Uso De Vídeos-Relatos: Construção E Avaliação De Uma Intervenção

Faria, 2010; Reisdoefer et al, 2017).

Por muito tempo se perpetuou a concepção dualista entre "razão" e "emoção" sobre o homem, colocado como um ser que ora pensa, ora sente. A "razão" sempre foi vista como responsável por controlar as emoções e alguns afirmavam que o conhecimento só se dava com ela, isso teve influência nos currículos escolares e nos processos educacionais desenvolvidos. Hoje, sabemos que as duas dimensões já não são mais dissociadas e que a afetividade tem sua força no meio escolar, contribuindo no sucesso do estudante. Condutas educacionais bem planejadas e desenvolvidas, também geram afetividade, o que nos aponta a importância que deve ser dada às práticas pedagógicas: ao que e como se aplica as atividades em sala de aula (Leite, 2012).

Dentre as condutas que contribuem na aproximação afetiva estão: propor objetivos que façam sentido ao estudante; investigar o conhecimento prévio do estudante para partir de um ponto relevante; organizar os conteúdos; escolher e executar com cuidado os métodos de aula e as atividades; se atentar aos procedimentos de avaliação e saber lidar com os resultados que os geram. A instituição deve planejar e agir em conjunto, a fim de garantir a coerência das ações (Leite, 2012). Mas, além de focar nas ações pedagógicas, é necessário que se leve em conta também, a diferença de experiência entre professor e estudante, que se correlacione o conhecimento com as experiências reais dos estudantes e que reconheça suas diferenças, sem ignorar as características particulares de cada um (Bulgraen, 2010).

Contudo, diante de todas as mudanças que têm surgido, o professor tem se encontrado em grandes desafios nas salas de aula, pois a acessibilidade à informação por outros meios, possibilita que parte dos estudantes cheguem com uma vasta bagagem (Rosa e Cecílio, 2010). Isso exige mudança também por parte dos docentes, que devem acompanhar a atualidade (Sordi, 2005) e o desenvolvimento dos estudantes mesmo sendo difícil sair do paradigma tradicional de ensino, que requer postura adequada e inovadora (Silva, 2000).

É necessário que o professor analise como os recursos existentes podem ajudar e que tenha clareza de suas concepções sobre a educação, mergulhando em suas próprias percepções e crenças, a fim de considerá-las para construção de um ensino melhor (Cinelli, 2003). Assim sendo, na próxima seção apresenta-se as contribuições da Psicobiologia à formação continuada de professores. 


\subsection{Contribuições da psicobiologia à formação continuada de professores}

\subsubsection{Estigmas, percepções e crenças}

É comum a sociedade categorizar pessoas e seus atributos, julgando o que é "normal" e "anormal". Se um indivíduo tem algo que o torna diferente de outros numa mesma categoria, deixando de ser considerado um ser "comum" para um ser com características que o faz diminuto, isso é um estigma (Ferreira et al. 2014; Goffman, 1963). As vítimas mais comuns são os dependentes químicos e os portadores de transtornos mentais, que têm a vida influenciada pela forma com que a sociedade trata o problema, gerando consequências afetivas, cognitivas e comportamentais, o que causa impacto em âmbito pessoal e social (Silveira et al. 2011).

Os estigmas podem estar presentes em qualquer meio, inclusive no escolar, o que torna fundamental o entendimento docente sobre determinados comportamentos, pois parece muito fácil atribuir diagnósticos aos estudantes e encaminhar crianças sem necessidade para um processo médico-psicológico, de modo a justificar o fracasso escolar. Entretanto, num paradoxo, falta sensibilidade e atenção por parte da escola em perceber a existência dos problemas e saber quando as devidas intervenções devem ser tomadas (Gimenez 2005).

As percepções e crenças que carregamos contribuem no molde da sociedade, nos conduzindo sobre o que é certo ou errado, pois afetam diretamente nossas reações e decisões (Antonelli-Ponti, Versuti \& Silva, 2018). No contexto escolar não é diferente, o que os professores percebem e acreditam, podem afetar seus comportamentos em sala de aula e o processo de ensino-aprendizagem, o qual pode se solidificar quando estratégias de ensino são aplicadas de forma fundamentada ou pode ser prejudicado quando se o que o professor acredita não vai de encontro com a realidade científica. Profissionais de âmbito escolar deve conseguir perceber o meio em que estão atuando, reconhecendo as dificuldades dos estudantes, para que se cumpra bem a tarefa de ensinar (Bejarano \& Carvalho, 2003; Pereira, 2017).

Apesar da palavra "crença" muitas vezes ser remetida à temática religiosa, seu uso em contexto científico tem ganhado força desde a década de 90 no Brasil. Investigações sobre crenças acerca da aprendizagem, as apontam como fator influente no processo de aprender, no comportamento e nas decisões docentes. Conceitua-se por ideias que as pessoas armazenam como resultado de experiências vividas, pelas interações e reflexões diante do que nos cercam(Barcelos, 2004). Pereira (2017) vai de encontro com a definição e ainda afirma que, tais experiências estão envolvidas por percepções. Além da influência que as crenças exercem 
Formação Continuada De Professores E O Uso De Vídeos-Relatos: Construção E Avaliação De Uma Intervenção

nas condutas e comportamentos, elas também podem influenciar as percepções (Bejarano \& Carvalho, 2003), isto é, percepções influenciam nas crenças e crenças influenciam nas percepções, muito embora tenham conceituações diferentes.

Em âmbito escolar, é muito importante que se leve em pauta as crenças de ensino, pois conhecer o que estudantes e professores acreditam, promove um entendimento sobre as consequências que elas acarretam em nossa vida e em nosso desenvolvimento pessoal, contribuindo na formação de indivíduos reflexivos e críticos sobre suas práticas, consequentemente fazendo uma educação mais eficiente (Barcelos, 2004).

"Percepção", por sua vez, também impacta nas tomadas de decisões (Antonelli-Ponti, 2016). Os comportamentos, em diversos âmbitos, podem ser reflexos disso, como um investimento parental materno por exemplo, que pode ser afetado pelo que a mãe percebe sobre as condições socioambientais (Tokumaru et al, 2011). Assim como condutas escolares, há estudos os quais apontam a influência das percepções nisso.

No estudo de Jou et al (2010), dentre 8.681 estudantes de 17 escolas de Porto Alegre, 384 foram apontados com TDAH pelos 136 professores investigados, e na verdade, 281 eram diagnosticados, mas, além da incompatibilidade entre a percepção e a realidade, duas escolas se destacaram pela grande diferença percentual de registros do transtorno, sendo uma de 51\%, enquanto a outra, apenas $0,2 \%$. A pergunta que norteou e esclareceu esses dados, foi sobre a conduta escolar em caso de suspeitas do transtorno. A escola de porcentagem maior, toma como regra, uma avaliação psiquiátrica mais imediata depois de dialogar com os pais. A escola de porcentagem menor, também comunica os pais, mas tem como norma de procedência, a tentativa de a equipe resolver junto às dificuldades dos estudantes, sobretudo, com orientações aos professores de como conduzi-los em sala de aula, e só depois mandam para uma avaliação psiquiátrica. As tomadas de decisões das equipes e os respectivos percentuais, mostram o impacto de um diagnóstico precoce (Pereira, 2017) e a relevância das medidas escolares.

Outro estudo investigou a percepção de 17 professores sobre os aspectos que tornam a aprendizagem mais efetiva, por meio da pergunta: “Como a relação entre professor e estudantes influencia na aprendizagem dos estudantes em Ciências e Matemática?”. O objetivo era compreender ações e saber como os professores pensavam. Os resultados foram separados em 3 categorias, pois citaram componentes fundamentais para a aprendizagem na relação entre professor-estudante (1); entre as atitudes dos estudantes (2); entre as atitudes do professor (3). Para (1), apontaram o afeto, harmonia, parceria, diálogo, respeito, reciprocidade e empatia; no (2), apontaram a confiança no professor, afinidade com a disciplina e compromisso com as aulas; e no (3), citaram o uso de métodos e recursos adequados, e conhecimento sobre a 
realidade dos estudantes. Mas, concluiu-se que a afetividade é o principal componente nas relações humanas, o ensino-aprendizagem se faz mais consistente quando há uma interação sócio afetiva entre quem ensina e quem aprende, e o incentivo nesse processo, compreende avanços na Educação (Reisdoefer et al, 2017).

Diante disso, há dimensões das relações interpessoais que podem ser usadas a favor da aprendizagem, tanto em aspecto abstrato, (envolvimento emocional), como num aspecto mais concreto, como uso de recursos e materiais. Tais artifícios podem ser considerados influências ambientais sobre o comportamento humano.

\subsubsection{Influências sobre o comportamento humano: Genética $x$ Ambiente}

O comportamento humano não é regido apenas por um único fator, ele é resultado da interação entre as influências genética e ambiental. A genética, corresponde aos atributos herdados de pai para filho e o ambiente aos fatores externos, isto é, todas as experiências que vivenciamos, seja ela positiva ou negativa. Essas forças se interagem, o que torna inapropriado vê-las separadamente e impossível discriminar o nível de importância entre elas (AntonelliPonti, 2016).

Os estudos que permitem analisar essas variações são experimentos naturais, que se dão por meio do processo de adoção e estudos com irmãos gêmeos. Fazem parte das investigações, indivíduos sem parentesco genético que compartilham o mesmo ambiente familiar e indivíduos com parentesco genético que não compartilham o mesmo ambiente. A semelhança de traços nos de sem parentesco genético, sugere a influência do ambiente sobre o comportamento, enquanto, nos indivíduos ligados geneticamente, porém separados, sugere a influência genética. Os estudos com irmãos gêmeos também apontam as variações das influências, pois os monozigóticos (idênticos) ou dizigóticos (não idênticos), mesmo que em porcentagem diferente, compartilham os genes. A combinação "adoção-gêmeos", consiste na comparação entre gêmeos separados e gêmeos criados juntos, e numa investigação sobre habilidade cognitiva, notaram que irmãos idênticos separados desde o início da vida, são quase tão parecidos quanto os que compartilhavam o mesmo ambiente, o que aponta, forte influência genética sobre o comportamento (Plomin et al. 2010).

Sempre houve uma tendência de se acreditar nos genes como responsáveis pelo controle dos seres, o que se caracteriza por uma crença no determinismo genético, na qual, negligencia as forças externas influentes na manifestação do comportamento. É inegável o poder da genética, mas, sem a ação do ambiente no componente orgânico nada ocorre, pois ele age como “ativador", essa interação gera a expressão dos genes, pois eles por si só não se manifestam 
Formação Continuada De Professores E O Uso De Vídeos-Relatos: Construção E Avaliação De Uma Intervenção

(Lipton, 2007).

A maneira como as pessoas percebem o comportamento e as influências que o cercam, determina como reagem uma à outra. Essa reação se inclui em todos os contextos, inclusive no escolar (Antonelli-Ponti, et al, 2018), por isso, é fundamental que o professor conheça e reconheça a importância dos estímulos ambientais, pois as experiências educacionais compõem o cenário ambiente das forças que regem o comportamento humano. $\mathrm{O}$ professor deve ter condições de atuar perante a diversidade que existe, e nesse sentido, oportuniza-lo com medidas formativas pode ser um caminho. A seção seguinte relaciona as contribuições descritas com perspectivas práticas para formação professores.

\subsection{Formação continuada de professores: lacunas e estratégias}

No âmbito da formação de professores, as propostas concentram-se na apresentação direta de conhecimentos sem a estruturação de condições para reflexão e aplicação desses conhecimentos na prática do professor (Sordi, 2005). Assim sendo, a concepção do conhecimento pronto e acabado perpetua-se neste contexto e a promoção do senso crítico e reflexivo distancia-se do cotidiano dos professores, evidenciando dimensões da informação para os docentes e não da formação. De acordo com Bolzan et al. (2013), há muito foco no conhecimento de áreas específicas e pouco se aborda "ensinar como ensinar" ou "como ser professor", e que isso faz o ensino ser visto como "transmissão de conhecimentos", pois há grande diferença entre "ensinar" e "produzir conhecimento".

Roldão (2007), conceitua a formação de professores como um processo contínuo de desenvolvimento profissional, que tem gerado preocupações aos sistemas e instituições educacionais pelas estratégias aplicadas e a maneira como são percebidas, pois muitas vezes, elas não estão em coerência com os objetivos propostos, gerando uma lacuna nas abordagens. Em desenvolvimento e constante evolução, estão também os sujeitos do processo (Imbernón, 2010), os professores, que devem conhecer suas facilidades e dificuldades para que reflitam sobre as atividades pedagógicas e cumpram bem suas tarefas, pois, ao mesmo tempo que podem ter um papel extremamente estratégico, eles podem ser dispensáveis se não estiverem caminhando com a atualidade (Bolzan et al. 2013; Molina \& Silva, 2002).

A atualização do professor se dá em vários sentidos, mas de forma inevitável, nos remete também aos avanços tecnológicos, que têm causado receio por parte dos educadores frente aos novos desafios, pois os anteriores meios de comunicação cultivavam indivíduos mais passivos, enquanto hoje, mais ativos e conectados pela interatividade que surgiu. É necessário que 
enfrentam essa realidade e estejam preparados para proporcionar um ensino mais atrativo perante a desmotivação dos estudantes (Costa \& Souza, 2017; Molina \& Silva, 2002).

Para integrar novas tecnologias à educação, é necessário criar condições favoráveis de apoio aos professores (Mercado, 1999), e contemplá-las na formação docente, pode ser uma opção, onde haja a inserção e uso adequado de novos instrumentos pedagógicos (Costa \& Souza, 2017). Isso requer a reconstrução de processos formativos e desenvolvimento de dispositivos e estratégias, sem deixar que revisitem suas práticas e concepções (Bolzan et al. 2013), formando assim, um ensino mais completo.

Há tempos, a formação continuada de professores está presente no cotidiano escolar, a fim de capacitar os profissionais envolvidos neste meio e garantir um sistema educacional mais qualificado. Essas oportunidades têm crescido e são apontadas pelas parcerias entre Secretarias de Educação e Universidades e indicativos virtuais. Em 2006, foi registrado 543.000 resultados para a frase "formação contínua de professores" (de Souza, 2006) num site de buscas na internet. Já em 2019, foi apresentado 14.100.000 resultados para a mesma expressão.

Os métodos de formação e suas estratégias devem acompanhar a atualidade, considerando o contexto social, as novas relações, informações e comunicação. Com isso, ao longo do tempo, as formações foram tendo características diferentes (Imbernón, 2010; Silva \& Araújo, 2005), como as propostas de Coelho e Nunes (2008) e Brandt e Moretti (2016) de formação continuada para professores em ciências exatas, onde proporcionaram práticas, como, oficinas, análise de vídeos, aplicação de atividades em sala de aula. Isso sem deixar de lado teorias e os artifícios para abordá-las.

Muitas das formações, parecem prezar por meios que promovem diálogo, exposição de ideias, trocas e reflexões (Andrade e Barbosa, 2016; Coelho e Nunes, 2008; Silva e Souza et al., 2018), seja por rodas de conversa, discussão mediada/orientada, lançamento de perguntas, exposição de temas (Filipin et al, 2016), entre outros.

A reflexão é uma prática sempre orientada para uma ação adequada e extremamente relevante ao ponto de vista do referenciado Paulo Freire, pois ela é a base da formação, sendo a janela para o professor se auto analisar e visitar suas condutas, saberes e decisões, o que ajuda na construção de seu perfil enquanto profissional (Silva \& Araújo, 2005).

A ideia é que as formações não deixem de lado suas características básicas, porém eficientes na contribuição do conhecimento, mas que agreguem estratégias inovadoras que possam ir de encontro com a atualidade, realidade e necessidade do público, como o uso de TDIC. 
Formação Continuada De Professores E O Uso De Vídeos-Relatos: Construção E Avaliação De Uma Intervenção

\subsubsection{Tecnologias Digitais da Informação e Comunicação (TDIC) e recursos educacionais}

A história da humanidade é marcada por fatos que causaram impactos culturais, sociais e pessoais, um mundo repleto de mudanças que produz sentidos, atualmente é fácil perceber o quão os surgimentos de outras épocas nos ajudaram e o quão as pessoas precisaram se adaptar. Assim, tem sido também com as novas tecnologias, Era da comunicação instrumentalizada, chamada por alguns de "Era Digital" (Costa e Souza, 2017).

Apesar de seu propósito facilitador (Costa e Souza, 2017) e de há tempos se ver as vantagens do seu uso no ambiente escolar (buscas e acesso à informação; estimulação da autonomia e da criatividade, que aumentariam a qualidade da escrita; o compartilhamento de trabalhos; divulgação na rede; preparação de aulas; visão ampliada dos temas por meio da internet) (Mercado, 1998), os educadores estão enfrentando um desafio em produzir aulas interessantes com métodos tradicionais, para atrair e prender a atenção dos estudantes, diante do poder que eles têm hoje nas mãos (Molina e Silva, 2002).

Há muitas propostas de reflexão sobre a utilização da tecnologia como recurso facilitador da prática pedagógica, e o professor, por ser membro fundamental da sociedade, precisa se encaixar às mudanças, que são constantes e chegam rápido (Sordi, 2005). A sociedade é dinâmica em suas relações e as tecnologias devem estar de acordo com a atualidade, sem deixar de ser aliadas às mais antigas (Souza e Souza, 2010; Pinheiro, 2016).

Cinelli (2003, p. 19) diz:

"Novas tecnologias surgem a cada dia, antes mesmo que a anterior seja completamente compreendida e dominada. É importante que a educação sem desprezar suas raízes, atue sobre o presente com os olhos voltados para futuro; que sem desprezar as ferramentas tradicionais, adote também as mais modernas".

O componente tecnológico deve fazer parte do processo de educação para que o ensino seja mais efetivo (Cabral e Rodrigues, 2016; Mercado 1998; Rosa e Cecílio, 2010), e a escola dispor de meios, para que se faça disso ferramentas de ensino e aprendizagem, já que o estudante hoje é representado pelo mundo da comunicação (Cinelli, 2003). Desse modo, podese trazer maneiras diferentes de ensinar diante da complexidade em que o processo consiste (Costa e Souza, 2017; Molina e Silva, n.d).

Mas, a assimilação e capacitação do docente são essenciais para que se tenha bons efeitos (Mercado, 1998), o professor deve estar ciente sobre o uso dos recursos tecnológicos, para que não gere a falsa impressão de que apenas ligar o computador seja suficiente, porque nem sempre esta inserção traz resultados positivos na aprendizagem e na dinâmica da turma (Miranda, 2007). 
Para que isso ocorra, é necessário alterar práticas, ter o verdadeiro entendimento do que se tem em mãos, se envolver com as atividades, orientar os estudantes e explorar ao máximo o que as tecnologias têm a oferecer (Miranda, 2007; Souza e Souza, 2010). A falta de formação para criar estratégias de ensino-aprendizagem com uso de tecnologias a e necessidade da modificação de concepções e práticas de ensino, são fatores apontados pelos próprios professores como obstáculos (Cabral e Rodrigues, 2016; Miranda, 2007). Mas, uma vez que se crie condições apropriadas, as tecnologias possibilitam que o estudante seja autor da própria aprendizagem, adquira autonomia, faça reflexões e desenvolva habilidades (Cabral \& Rodrigues, 2016; Silva, 2000; Pinheiro 2016).

O termo TDIC significa, Tecnologias Digitais de Informação e Comunicação, e é associado com informática, rede de computadores, internet, multimídia, pois outras tecnologias anteriormente existentes, como: telefone, rádio, vídeos, áudio, TV, foram integradas por meio do computador e seus periféricos (Miranda, 2007; Costa e Souza, 2017).

As TDIC são ferramentas influentes em nossa vida, pois além de proporcionar conhecimento, podem promover mudanças de comportamentos, como é o caso da televisão, mídia, canais, programas. Aparentemente, uma simples propaganda de "sabonete", gere efeitos sobre a fertilidade e empoderamento da mulher (Bernard et al., 2015).

\subsubsection{Uso de vídeos e seu potencial na mudança de percepções e comportamento}

Desde muito cedo nos interessamos por imagens e sons, e somos expostos a diferentes meios de comunicação - televisão, revistas, rádios, cinema - que estimulam e modificam nosso cérebro. Os vídeos, à exemplo dos conteúdos exibidos nas televisões, envolvem trocas de ideias, geram crenças e sentimentos que podem promover mudanças no comportamento dos telespectadores e garantem informações de cunho científico (Cinelli, 2003; Martins, 2010).

Na década de 70 já se falava sobre o uso de vídeos nas escolas e sua utilização como ferramenta educativa, que promove contextualização e extensão do conhecimento, pois nos faz ir muito além do conteúdo expresso. Tornou-se um recurso a mais ao professor e também passou a compor a bagagem de informação que os estudantes chegam à sala de aula (Cabral e Rodrigues, 2016; Cinelli, 2003; Rosa e Cecílio, 2010).

A incorporação de tecnologias pode vincular contextos de ensino e culturas que se desenvolvem fora do meio escolar (Cabral e Rodrigues, 2016), e alguns estudos da Economia Comportamental confirmam isso. A Economia Comportamental é uma ciência-ponte que interliga a Psicologia às Ciências Econômicas, onde economistas exploram temas de interesses 
Formação Continuada De Professores E O Uso De Vídeos-Relatos: Construção E Avaliação De Uma Intervenção

a partir dos conhecimentos de psicólogos. Ela oferece um arcabouço teórico, que muito tem a dizer sobre os efeitos de controles sociais sobre o comportamento humano (Franceschini e Ferreira, 2012).

Moradores da Etiópia assistiram documentários sobre pessoas de comunidade similares, as quais tiveram a posição socioeconômica melhorada (agricultura e demais negócios conquistados) sem ajuda de governo e/ou ONGs. O objetivo do estudo era alterar as aspirações dos participantes. Pessoas pobres geralmente não fazem investimentos mesmo quando o retorno é alto (Bernard et al., 2014). A hipótese dos autores para explicar esse comportamento, é que elas possuem baixas "aspirações" (i.e., "ambição para conseguir algo"), formando modelos mentais que ignoram opções de investimento maiores, por não acreditar que a mudança seja possível.

Bernard et al. (2014) realizaram um estudo com vídeos com estudantes mulheres de cálculo, estas relataram aumento nas crenças de auto eficácia nas disciplinas e carreira futura, após serem expostas a fotografias e vídeos de modelos femininos na ciência. Os resultados analisados 6 meses após a intervenção, foram positivos, pois a alteração refletiu na poupança, uso de crédito, matrículas de crianças nas escolas e gastos mais voltados à educação. Portanto, sugerem que mudar as aspirações, pode mudar comportamentos voltados ao futuro. As aspirações evoluem em resposta às circunstâncias e experiências de vida, e se empregar no lugar do outro num plano semelhante, que trouxe resultados benéficos aos submetidos.

Em continuidade, Bernard et al. (2015), usaram intervenções com vídeos para verificar sua eficácia na indução de mudanças comportamentais em pessoas de países pobres da África. O método aplicado foi a exposição à documentários com relatos de outros indivíduos (homens e mulheres) da mesma região, que mudaram a posição econômica de baixa para média, apontando definição de objetivos, escolhas cuidadosas e trabalho árduo que realizaram relacionados ao sucesso em agricultura e em negócio comercial. Aleatoriamente, os indivíduos foram divididos em grupo controle e grupo da triagem do documentário. Foram apresentados para 64 aldeias 4 documentários de 15 minutos cada com relatos de sujeitos com origem semelhante ao do telespectador. Atender as especificidades do público, adaptando as mensagens de acordo com as necessidades de informação do indivíduo garante maior poder na mudança de comportamento, pois o telespectador se relaciona com o personagem que está assistindo. Quando há conexão emocional, o indivíduo revê seu comportamento diante do que está vendo, e se há compartilhamento de características entre expositor e visualizador essa ação tende a ser maior. As pessoas recebem melhor as mensagens daqueles que reconhecem como similares, sugerindo que os comportamentos são fortemente afetados pela experiência dos outros (Bernard 
et al., 2015).

Cohen, Swerdlik e Sturman (2014), realizaram estudos com policiais foram treinados a escolher melhores estratégias de ação assistindo vídeos de ocorrências reais e discutindo suas ideias com treinadores experientes, o que aponta a relevância desse instrumento em desempenhar funções em algumas situações. Esse modelo pode ser redirecionado a outros profissionais, e considerando uma formação continuada de professores, eles podem assistir gravações de situações em que se colocariam no lugar, e responder como lidariam com determinados estudantes dentro de uma sala de aula diante do que viram.

Segundo Costa e Souza (2017): “As TDIC's estão exercendo um papel cada vez mais importante na forma de nos comunicarmos, aprendermos e vivermos" (p. 221). Mesmo fora da sala de aula, elas contribuem na aprendizagem, auxiliando nos estudos de forma estimulante, pois mexem com a criatividade e transformam tarefas árduas em positivas (Souza e Souza, 2010).

$\mathrm{Na}$ Alemanha, foi realizada uma intervenção de caráter interativa sobre o tema "obesidade", a fim de reduzir estigmas a respeito do assunto e ensinar sobre sua etiologia. O método se deu por uma apresentação de slides audiovisual e teve duração de 60 minutos. Um dos objetivos era gerar reflexão sobre os pensamentos e atitudes em relação aos indivíduos com sobrepeso, então, foram utilizadas técnicas de psicoeducação, descoberta guiada e imagética mental. O módulo 1 informou sobre definição, prevalência, fatores de risco e tratamento da obesidade com ênfase na interação entre fatores genéticos e ambientais, e na limitada mudança do corpo pelos tratamentos de perda de peso; o módulo 2 abordou sobre a pressão social por meio da imagem corporal para as pessoas serem magras; o módulo 3 contemplou o tema "preconceito", apresentando a origem do estigma em relação ao peso, formas de discriminação e suas consequências. Foi também projetada uma tarefa de reflexão para conscientizar os participantes sobre seu próprio preconceito. Os resultados apontaram que houve uma mudança, os estigmas reduziram duas semanas após a intervenção, confirmando as evidências sobre o potencial de programas multicomponentes, mesmo com o breve tempo de aplicação (Hilbert, 2016).

Numa abordagem de formação pedagógica na área da saúde, estudantes de mestrado da disciplina Tecnologias da Informação e Comunicação da Universidade Estadual do Ceará criaram um vídeo educacional e aplicaram para uma turma de 16 estudantes do oitavo semestre de medicina, por considerarem a transformação educacional uma necessidade decorrente dos avanços tecnológicos. Os estudantes sugerem o uso de vídeos como estratégia de formação docente para o ensino de saúde, já que parcela dos graduados seguem a carreira acadêmica, mas 
Formação Continuada De Professores E O Uso De Vídeos-Relatos: Construção E Avaliação De Uma Intervenção

não possuem base suficiente para lidar com os processos de ensino- aprendizagem. Os participantes afirmaram ter rompido estigmas que carregavam sobre o assunto e que a estratégia impactou nas mudanças de condutas e que promoveu a aprendizagem significativa (Lima et al, 2019).

Neste sentido, destaca-se o potencial do uso de vídeos, no contexto educacional, como sendo uma ferramenta adequada (enquanto recurso tecnológico) para promover o ensinoaprendizagem, garantindo a dinamicidade das aulas, a atenção dos estudantes e a mediação docente (Lima et al., 2019). O uso de vídeos muda o comportamento em sala de aula, ela atrai o estudante, contribui na interação e descontração da turma, gerando consequentemente exposição e debate de opiniões (Andrade e Barbosa, 2016).

Diante das potencialidades do recurso e da relevância de alguns comportamentos em âmbito educacional pela perspectiva de Walker e Plomin (2005), houve interesse em construir vídeos sobre as influências do comportamento. Os domínios considerados pelos autores são: personalidade, inteligência, problemas do comportamento, dificuldades de aprendizagem e doenças mentais. A pesquisa incluiu os dois últimos. Sendo os vídeos ferramentas capazes de mudar percepções e condutas, seu uso se faz importante em outras esferas que não o público discente. A aplicação à comunidade docente (parte do atual estudo), levou informações sobre aspectos do comportamento, que podem interferir diretamente no processo de ensinoaprendizagem. Na seção seguinte apresenta-se os principais aspectos do comportamento, denominadas de domínios do comportamento humano que impactam no processo de ensinoaprendizagem, considerados neste estudo.

\subsection{Domínios do comportamento relevantes no ambiente educacional}

\subsubsection{Dificuldades de Aprendizagem}

O tema aprendizagem teve destaque no cenário científico entre as décadas de 1950 e 1970, e junto com ele, as dúvidas sobre o processo de aprender foram surgindo, mas, ainda existem controvérsias sobre definições. A aprendizagem é um processo constante e bilateral (quem aprende e quem ensina), que implica em modificações no comportamento do indivíduo, tanto de forma biológica (já que o ser humano estabelece relações com o mundo por meio de sistemas cerebrais específicos); quanto de forma respondente, agindo como atuante ou atuado ao meio em que está inserido (Ciasca, 2004).

Jean Piaget, se dedicou à epistemologia genética, ou seja, construiu uma teoria focada na origem do conhecimento nos seres humanos, levando em conta a base biológica do 
funcionamento psicológico delineou pressupostos teóricos e metodológicos que permitiram compreender como o conhecimento é construído gradualmente. Assim sendo, ao acreditar que os processos filogenéticos e ontogenéticos tinham implicações diretas no desenvolvimento, considerava que a escola deve respeitar a criança e oferecer condições para que ela se desenvolva. A escola e o professor são essenciais no processo, pois compõem essas experiências (Treviso e Almeida, 2014). O educador no papel de orientar, estimular e desenvolver estratégias, contribui efetivamente na construção do conhecimento e da aprendizagem.

Há autores que se dedicam a compreender lacunas nos processos de ensinar e de aprender e procuram romper com associações simplistas vinculadas à incapacidade individual de aprender. Alguns termos utilizados são: dificuldades de aprendizagem, dificuldades na aprendizagem, dificuldades escolares, problemas de aprendizagem, problemas na aprendizagem, distúrbio de aprendizagem, transtorno de aprendizagem. Apresenta-se a seguir uma breve descrição destes termos.

O "Distúrbio de Aprendizagem", está associado especificamente às disfunções neurológicas ou neuropsicológicas, caracterizadas por uma condição biológica, que envolve alterações do Sistema Nervoso Central, relacionadas a "defeitos" na aquisição e no desenvolvimento do indivíduo. É algo intrínseco, que por consequência traz dificuldades na aquisição de linguagens (escrita, fala e leitura), no raciocínio e habilidades exatas, mas, que pode ter influências ambientais também (Ciasca, 2004; Hammil, 1990).

As "Dificuldades de Aprendizagem" (DA) já é algo mais amplo, podendo ser qualquer tipo de dificuldade no processo de aprender e pode ter o envolvimento de vários fatores, como, condição pessoal, emocional, cultural, social, familiar, educacional. É praticamente impossível atribuir um único motivo ao problema, pois se aprender é um processo que depende da interação com o meio, a DA é o impedimento nessa interação. Esse impedimento pode ser de caráter neurobiológico, cognitivo, genético, pedagógico (Gimenez, 2005; Da Silva, 2015). Isto é, a DA é uma consequência, uma manifestação de outros problemas, que inclusive podem ter causas orgânicas, como o "Distúrbio de Aprendizagem".

É comum que as crianças apresentem dificuldades no início da alfabetização (Schirmer et al, 2004) e que elas sejam manifestadas no meio escolar, já que é o ambiente onde o ensinoaprendizagem se dá em sua maioria ao longo de nossa vida. Mas, nem sempre elas são notadas, pois ainda falta conhecimento por parte dos educadores para detectar os problemas e trabalhalos de maneira adequada. A escola, devendo ter as condições para atender as particularidades dos estudantes, nos aponta a necessidade de formações continuadas aos profissionais do sistema 
Formação Continuada De Professores E O Uso De Vídeos-Relatos: Construção E Avaliação De Uma Intervenção

educacional, que devem agir integradamente para contribuir na aprendizagem significativa dos estudantes (Da Silva, 2015).

\subsubsection{Doenças Mentais}

O termo "Doenças mentais" ou "Transtornos mentais" pode comprometer o desempenho do sujeito em vários aspectos. Pode afetar a cognição, desregular as emoções e alterar comportamentos (Araújo e Neto, 2014). No que se refere a esse domínio, tratamos na atual pesquisa como "Doenças mentais", assim colocado por Walker e Plomin (2005), que consideram um traço relevante no processo educacional. Algumas, estão diretamente relacionadas ao processo de aprender, como os Transtornos Específicos de Aprendizagem, outras, afetam indiretamente, como a ansiedade generalizada, por exemplo.

A prevalência de doenças mentais a nível mundial é assustadora, em torno de 700 milhões de pessoas são atingidas pelo problema, sobretudo, pela depressão e ansiedade. $\mathrm{O}$ Brasil ocupa o quinto lugar do ranking mundial em depressão e o primeiro lugar em ansiedade (Costa e Nebel, 2018).

Apesar das causas genéticas, é visto o quão o ambiente exerce influência sobre esse domínio. Embora todas as pessoas estejam sujeitas, meios desfavoráveis e vulnerabilidade social, aumentam as frequências de psicopatologias pela falta de apoio e atenção pública. Para mapear a população, contribuir no diagnóstico e conhecer de perto as causas dos problemas, sugere-se um psicodiagnóstico. A precariedade educacional é um dos fatores (Grana e Bastos, 2010), e sendo um segmento que em sua imperfeição traz prejuízos, pode-se afirmar, que um investimento na qualidade traz bons resultados.

Cabe ao professor perceber determinadas situações em sala de aula para que os métodos de ensino aplicados sejam apropriados à cada caso e a aprendizagem do estudante seja favorecida, pois é objetivo da escola promover a qualidade da aprendizagem, que não é um comportamento em si, mas sim uma alteração das condições do meio ambiente num sistema de eventos inter-relacionados (Ciasca, 2004; Reisdoefer et al., 2017).

A falta de conhecimento sobre os problemas que o estudante possa estar enfrentando, a ausência de ações docentes e a escassez de suporte das escolas, são fatores contribuintes ao fracasso escolar do indivíduo, que está intimamente ligado ao ato de aprender (Alves et al., 2018; Jou et al., 2010). O desempenho do estudante não constitui uma problemática individual, e sim um conjunto de variáveis, desde a escola e a proposta pedagógica; os professores, formação, crenças e práticas; os estudantes e suas capacidades; até seus familiares. A influência que o ambiente exerce sobre as dificuldades dos estudantes, nos indica a relevância de investir 
em mudanças educacionais para promover um ensino mais consistente (Gimenez, 2005).

O professor deve ser submetido a formações e capacitações para que recebam apoio e instruções quanto às medidas usadas em sala de aula e se faça reconhecer a importância. MaiaPinto e Fleith (2002) afirmam a existência de professores incrédulos sobre a influência da escola em casos de estudantes superdotados. O mesmo estudo aponta uma percepção defasada sobre a superdotação e o pouco investimento em estratégias educacionais nestes casos.

A relevância do atual trabalho é a contribuição à comunidade docente com o desenvolvimento e aplicação de uma intervenção com mediação tecnológica voltada à formação continuada de professores, a fim de contribuir em algumas lacunas que existem nesse processo (Roldão, 2007; Sordi, 2005).

A hipótese é que a intervenção possa ser sugerida como uma prática viável e eficaz para formação, atuando nas percepções docentes sobre alguns comportamentos relevantes em âmbito educacional, de modo que sejam favoráveis no processo de ensino-aprendizagem. Assim sendo, a próxima seção trata de alguns diagnósticos dados aos estudantes que afetam o desempenho na escola.

\subsection{Diagnósticos que afetam o desempenho}

\subsubsection{TDA е TDAH}

O Transtorno de Déficit de Atenção e Hiperatividade (TDAH) é um Transtorno do Neurodesenvolvimento, que ocorre em $5 \%$ das crianças e 2,5\% dos adultos, e se caracteriza pela persistente desatenção, hiperatividade e impulsividade. Respectivamente, essas características geram: dificuldade em manter o foco; atividade motora excessiva (nas crianças) e inquietude extrema (nos adultos); e falta de controle dos impulsos (DSM-5, 2014). Os sintomas do TDAH no que se refere à desatenção são: dificuldade de prestar atenção a detalhes; cometer erros por descuidos; dificuldade para manter a atenção nas tarefas; parecer não escutar quando lhe dirigem a palavra; não seguir instruções; não terminar tarefas; ser desorganizado; ser distraído; apresentar corriqueiros esquecimentos. No que se refere à hiperatividade são: agitar as mãos e/ou os pés; remexer-se em excesso e/ou abandona assentos; correr ou escalar em lugares inapropriados; falar muito e não esperar a vez; fazer barulhos; impulsividade; (Jou et al., 2010; Rohde et al., 2000).

Apesar do TDAH não ser um transtorno específico de aprendizagem, sua presença pode comprometer o desempenho do indivíduo e afetar a vida escolar, pois maioria das crianças com 
Formação Continuada De Professores E O Uso De Vídeos-Relatos: Construção E Avaliação De Uma Intervenção

o transtorno tem dificuldades na escola (Schirmer et al., 2004). É comum que portadores sejam apontados como preguiçosos e irresponsáveis, mas, para evitar que eles passem despercebidos (sem receber o tratamento adequado) e que rótulos sejam dados aos indivíduos não portadores, deve haver uma investigação profissional cautelosa e um diagnóstico atencioso, pois o transtorno tem sido usado também como justificativa de muitos problemas escolares (Da Silva, 2005; DSM-5, 2014). Professor não pode diagnosticar, mas sua percepção é muitas vezes, a responsável pelo encaminhamento adequado do estudante, sendo a escola num todo, peça chave no processo de diagnóstico, pois é rica fonte de informação sobre o comportamento dos estudantes, já que é o ambiente comum de se notar os problemas pelos afazeres que são atribuídos (Graeff e Vaz, 2008; Jou et al., 2010; Rohde et al., 2000).

O TDA consiste na ausência do sintoma de Hiperatividade, mas como a atenção é um fator primordial para a qualidade da aprendizagem (Hora et al., 2015; Moraes et al., 2007), o indivíduo com o transtorno pode ser prejudicado, e cuidar do problema ameniza tudo que pode ser acarretado. O tratamento pode ter uma abordagem múltipla, com intervenção psicossocial, farmacológica, educacional, que se caracteriza pelo uso de materiais e métodos de ensino específicos. A escola pode ser fonte de estímulos e as condutas tomadas podem gerar grandes impactos, isto significa que, se professores forem irredutíveis e usar métodos inapropriados às necessidades dos estudantes, eles podem sofrer consequências, como: notas baixas, reprova, percepção negativa de si mesmo, caso contrário, os resultados serão positivos e terão mais sucesso na vida estudantil (Da Silva, 2005; Jou et al., 2010; Rohde et al., 2000).

\subsubsection{Síndrome de Irlen}

A Síndrome de Irlen (SI) se caracteriza por distorções visuoperceptuais ou sobreposições de imagens consecutivas, que são percebidas mais facilmente em atividades que demanda atenção visual, como a leitura (Faria, 2011; Irlen e Robinson, 1996; Kriss e Evans, 2005). Os sintomas físico-oculares do problema geralmente são: ardência, dor e cansaço visual, cefaleia, lacrimejamento, excesso em apertar e esfregar os olhos. A síndrome é manifestada também por sensibilidade à luz, déficit na percepção de profundidade, canseira e lentidão progressiva na leitura, além das distorções na percepção visual textual, que se apresentam, com: sombras, espaçamentos irregulares, movimentos e ondulação das letras. Tudo isso, reduz a oportunidade de aprendizagem e afeta uma das aquisições de linguagem mais importantes no processo de aprender, a leitura. Geralmente os sintomas aparecem na fase escolar, pois é o momento em que se tem maior contato com textos e folhas brancas. (Alves et al., 2018; Garcia 
et al., 2018). A Professora Dra. Marcia Reis Guimarães da Fundação H. Olhos de Belo Horizonte (existente há mais de 30 anos e reconhecida internacionalmente pelos tratamentos em distúrbios visuais), afirma que crianças com até 12 anos, em média $75 \%$ da aprendizagem dependa da visão.

O sistema visual é uma perfeita arquitetura, e como parte indispensável, tem a luz, pois os olhos coletam raios de luz emitidos ou refletidos por objetos no ambiente para a formação de imagens (Bear et al., 2008), portanto, qualquer interferência nessa funcionalidade, a visão pode ser comprometida. No site da Fundação H. Olhos, a Dra. Marcia Reis Guimarães enfatiza que: "a visão é uma habilidade cerebral e que o olho é um captador de estímulos luminosos, transformando-os em estímulos neurológicos”. As aparentes explicações são relacionadas ao déficit de processamento das informações visuais que envolve o movimento dos olhos, ação que tem relação direta com a leitura, pois o direcionamento rápido para a próxima palavra, pode gerar uma sobreposição de imagens; a hipersensibilidade no sistema visual é outro motivo, cuja atrapalha o processamento cerebral das informações recebidas e reduz a qualidade de interpretação, trazendo como prejuízos: leitura mais lenta, inversão de palavras, confusão com as linhas do texto; que por suas vezes, geram a perda de foco, sonolência, irritabilidade (Faria, 2011; Irlen e Robinson, 1996).

A intervenção está relacionada com a filtragem de cores, como, o uso de folhas coloridas de acetato transparente, que são sobrepostas aos textos e prescritas individualmente, a fim de diminuir a distorção na percepção dos textos (Irlen e Robinson, 1996; Kriss e Evans, 2005; Wilkins et al., 1991). Elas são conhecidas como Overlays e a coloração é testada e escolhida pelo próprio indivíduo, que varia de acordo com a gravidade da síndrome, e o uso das cores pode se dar, tanto pelas lâminas espectrais (Overlays), como por filtros adaptados em lentes de óculos. Uma em cada dez crianças relatam melhora no processo de leitura com o uso das sobreposições (Alves et al., 2018; Garcia et al., 2018).

Devido as consequências, parece haver uma relação entre Síndrome de Irlen e Dislexia, porém, a dislexia não se associa com sensibilidade visual, e sim, com o envolvimento de áreas no cérebro, que se manifesta com alterações auditivas, orais e de linguagem (Rotta et al., 2015). A SI afeta uma aquisição de linguagem (leitura), enquanto a dislexia, é um distúrbio da aquisição de linguagem em si (Schirmer, 2004), isto é, são disfunções que requerem atenção, diagnósticos e tratamentos diferentes, evitando assim, o comprometimento da aprendizagem. 
Formação Continuada De Professores E O Uso De Vídeos-Relatos: Construção E Avaliação De Uma Intervenção

\subsubsection{Transtorno do Espectro Autista (TEA)}

O Transtorno do Espectro Autista (TEA) é um Transtorno do Neurodesenvolvimento, que tem prevalência de $1 \%$ da população, acomete quatro vezes mais o sexo masculino, tem causas genéticas e ambientais e o diagnóstico se dá pela frequência e intensidade dos sintomas. Existem níveis de gravidade, e quando atinge de forma severa, os sinais aparecem até o primeiro ano de vida, geralmente notado pela ausência de contato visual e associado à surdez pela falta de interação, mas no geral é percebido um atraso no desenvolvimento infantil. O termo espectro vem da variação de manifestações e as características mais conhecidas são: déficit nas interações sociais, déficit nas relações socioemocionais e comportamentos estereotipados. Existem outros sintomas que podem aparecer, como: anormalidade na comunicação verbal e não verbal, comportamentos repetitivos (fala, uso de objetos e atividades motoras), desinteresse em relacionamentos, não se expressar emocionalmente e gestualmente, se manter solitário, diferentes reações aos estímulos ambientais (como, luz, cheiro, temperatura), interesse por objetos giratórios (como, ventilador, hélices), comportamentos ritualizados e dificuldade com transições e alteração de rotina, etc. Mas, principalmente, o que marca o transtorno é a repetição de comportamentos, interesses e atividades e o prejuízo na comunicação e interação social, sinais bem notáveis já nas crianças pequenas, pois não interagem, não compartilham emoções e não imitam o que ensinam; quando nos adultos, tais sinais aparecem em dificuldade no processamento do que ou não fazer e falar, resultando numa linguagem limitada e unilateral (DSM - 5, 2014).

O TEA está citado como uma disfunção que pode afetar a aprendizagem, porque apesar dos autistas poderem apresentar níveis de inteligência como de qualquer outra pessoa, é natural que se tenha um comprometimento nas habilidades e capacidades, justamente devido aos déficits de comunicação e interação. Ele influencia na vida social, estudantil e profissional do indivíduo, pois além de todas as limitações, as dificuldades de organização, planejamento e mudanças estão também presentes e trazem grandes impactos (DSM - 5, 2014).

O TEA não tem cura e os sintomas sempre serão empecilhos para uma vida totalmente normal, entretanto, o diagnóstico e algumas intervenções são bastante eficazes em determinados contextos e quanto antes acontecerem, maiores as chances de sucesso. É importante considerar os níveis de transtorno e as particularidades de cada autista. Não existe exames genéticos para o diagnóstico, mas uma vez confirmado, o tratamento adequado é essencial. Dentre as possíveis intervenções, a psicoterapia comportamental é a mais recomendada para trabalhar diversas questão, inclusive a aprendizagem; a Análise Aplicada do Comportamento (ABA) é um método 
que trabalha instruções por etapas, a fim de ampliar as habilidades e também a aprendizagem pelo reconhecimento de diferentes estímulos; para contribuir na compreensão e comunicação do indivíduo, há o método de comunicação por meio de recursos físicos e visuais do programa PÈCS (Picture Exchange Communication System), como a utilização de imagens, placas, objetos, vídeos; a linguagem de sinais também é uma opção (Onzi e Gomes, 2015). Tais métodos são consistentes de acordo com as dificuldades do autista e podem ser aplicados em paralelo com a vida escolar, além do mais, muitos deles incluem artifícios possíveis de adotar na própria sala de aula.

\subsubsection{Dislexia}

De acordo com o DSM-5 (2014), a Dislexia é um Transtorno Específico de Aprendizagem, cujo se caracteriza por dificuldades na aprendizagem e nas habilidades acadêmicas com persistência de sintoma (s) por pelo menos seis meses, como: dificuldades na leitura e na compreensão do que leu; dificuldade na escrita; dificuldades numéricas e de raciocínio. A dislexia gera prejuízos na precisão, velocidade e compreensão da leitura; na ortografia, gramática, pontuação e organização da expressão escrita. No geral, a dislexia envolve problemas com decodificação e compreensão das "palavras" e discalculia envolve problemas com os "números".

A dislexia por ser um distúrbio de aquisição de linguagem, tem relação direta com a aprendizagem, pois afeta processos de suma importância para aprender, a leitura e a escrita. As causas são orgânicas, mas os fatores externos têm muita influência sobre o problema, como os métodos de ensino, por exemplo (Schirmer et al., 2004). Os sinais começam a ser percebidos no período da alfabetização e o diagnóstico acontece um pouco mais tarde, quando a própria criança já percebe que tem algo errado e se sente inferior em relação aos outros estudantes, pois não consegue se desenvolver da mesma maneira. O embaraço fica perceptível aos pais, que muitas vezes nem imaginam o real motivo do problema, e aos professores, que são fundamentais para reconhecer a alteração e fazer o devido encaminhamento para que o suspeito seja analisado por profissionais da área (Da Silva, 2015).

Para o diagnóstico, algumas questões são levantadas, como: velocidade e fluidez da leitura, medo de ler em voz alta, presença de disléxico na família, dificuldade em soletrar, má compreensão do que foi lido, retardo da linguagem oral, troca de letras nas palavras e de palavras nas frases, entre outras coisas. Quanto mais precocemente o diagnóstico for realizado, melhor é para a definição de estratégias interventivas e para a absorção do conteúdo, pois é na 
Formação Continuada De Professores E O Uso De Vídeos-Relatos: Construção E Avaliação De Uma Intervenção

infância que há maior plasticidade cerebral. As intervenções parecem ser aplicáveis em diferentes circunstâncias, sobretudo, se houver consciência e apoio da família; deve haver um trabalho em conjunto, incluindo a escola, pois é o local onde o indivíduo dá início às aquisições de linguagem e tem contato direto com o ensino-aprendizagem, parecendo assim, que as estratégias aplicadas nesse ambiente são as mais indicadas (Deuschle e Cechella, 2009).

\subsubsection{Ansiedade Generalizada}

A ansiedade é uma emoção, assim como raiva, amor, ódio, e emoção por sua vez, é um fenômeno que afeta o corpo, pensamentos e comportamentos. Apesar dos sintomas serem incômodos, a ansiedade é uma característica evolutiva com funções adaptativas à nossa sobrevivência. Nessa perspectiva, as reações as quais nos ocorrem não é por acaso, elas são contribuintes para estarmos aqui hoje (Freeman e Freeman, 2015). Embora muitas vezes, ansiedade e medo sejam vistos como sinônimos, a diferença se dá principalmente, pelo momento em que os sintomas manifestam, enquanto o medo é uma resposta instantânea à uma situação de risco, a ansiedade é uma preocupação antecipada da ameaça. No medo, o corpo se prepara para a fuga (remoção do estímulo aversivo), e na ansiedade, o corpo se prepara para a esquiva (prevenção do estímulo aversivo), ocasionando sintomas evolutivamente explicados: taquicardia, para o sangue ir mais rapidamente aos músculos e correr melhor; olhos arregalados pela dilatação das pupilas para enxergar melhor; respiração intensa e abertura das narinas para melhor percepção de odores; entre outros. Além disso, ela gera preocupação, irritação, comprometimento do sono e de concentração (DSM-5, 2014).

O que faz a ansiedade sair do seu estado normal e atingir um nível patológico é o aparecimento de sintomas em quantidade e intensidade incompatíveis às situações que os geram, deixando de ser apenas uma emoção e virando um transtorno mental. Quando isso ocorre, chamamos de "Transtorno de Ansiedade Generalizada", caracterizada sobretudo, pelos prejuízos que o indivíduo passa a ter, pois ela afeta diretamente os afazeres do dia a dia (Braga et al., 2010).

O TAG é um dos transtornos de ansiedade listados pelo DSM-5, que tem grande incidência em diferentes lugares do mundo, atinge em sua maioria as mulheres (proporção 2:1), acomete pessoas das mais variadas idades e tem a preocupação excessiva como sintoma predominante. O indivíduo que possui, se preocupa em nível desproporcional e sempre pensa no pior, até nas situações mais corriqueiras, no entanto, para ser diagnosticado, é necessário que seja avaliado por um profissional e que os sintomas estejam presentes no por mínimo 6 meses. 
Os gatilhos para o surgimento são genéticos e ambientais, e pode-se afirmar que traumas são fatores de riscos para seu surgimento, que uma vez presente, aumentam as chances para outros problemas mentais, como a depressão, transtorno psiquiátrico que frequentemente acompanha o transtorno (Brentini et al., 2018; Stein e Sareen, 2015).

Embora o TAG aparentemente não tenha relação direta com o processo de aprendizagem, ela pode ser afetada, pois, apesar do transtorno não ter características de déficits nas aquisições em si, os sintomas podem prejudicar as oportunidades de aprender, pelas possíveis esquivas que o indivíduo possa cometer, pela frequente desconcentração e persistente preocupação.

\section{Objetivos}

\subsection{Objetivos Gerais}

Construir, aplicar e ver a viabilidade de uma intervenção como proposta de formação continuada para professores.

\subsection{Objetivos Específicos}

a) verificar a realização das atividades propostas na intervenção;

b) caracterizar o efeito da intervenção sobre as percepções docentes em relação as influências genéticas e ambientais sobre dificuldades de aprendizagem e doenças mentais;

c) caracterizar o efeito da intervenção sobre a atitude do professor perante um estudante com dificuldade de aprendizagem geneticamente influenciada.

\section{Métodos}

\subsection{Aspectos éticos}

A pesquisa garantiu os procedimentos éticos e foi aprovada pelo Comitê de Ética em Pesquisa desta Universidade, parecer consubstanciado $\mathrm{N}^{\circ} 771.808 \quad\left(\mathrm{n} .{ }^{\circ}\right.$ CAAE 79030917.1.0000.5407). Todos os participantes assinaram os devidos termos (Termo de Consentimento, Termo de Assentimento e Termo de Armazenamento de Dados) onde continham todos os esclarecimentos sobre os requisitos de participação e desistência da pesquisa (Apêndices A, B, C e D). 
Formação Continuada De Professores E O Uso De Vídeos-Relatos: Construção E Avaliação De Uma Intervenção

\subsection{Delineamento da pesquisa}

O delineamento desta pesquisa consistiu em: descrição da construção de uma intervenção e descrição da aplicação da intervenção. Para testar a viabilidade, foi realizada uma análise qualitativa: respostas dos professores coletadas durante a intervenção; e uma análise quantitativa: respostas dos professores coletadas antes e após a intervenção.

\subsection{Construção da intervenção}

\subsubsection{Vídeos-relatos}

Os vídeos foram construidos por meio de relatos de indivíduos com dificuldades percebidas e/ou diagnosticadas. As pesquisadoras da pesquisa foram as responsáveis pelo recrutamento dos participantes, os quais deveriam ter dificuldades que tivessem interferido de alguma forma na vida escolar, mas que já tivessem superado o problema e desenvolvido habilidades por meio de estratégias e intervenções viabilizadas por diferentes atores sociais, que romperam com prognósticos negativos e produziram respostas adequadas socialmente, evidenciando uma história de enfrentamento e resolução positiva de problemas relacionadas com o sucesso acadêmico e pessoal destes sujeitos.

Os vídeos foram elaborados e produzidos com a participação prévia de crianças, adolescentes, adultos, seus pais, professores e outros profissionais envolvidos, os quais foram informados sobre a utilização de sua imagem exclusivamente para fins de estudo e assinaram o termo de consentimento livre e esclarecido, termo de assentimento livre e esclarecido e termo de autorização para uso de imagem.

Os vídeos relataram sobre as medidas adotadas, as quais incluíram tratamento medicamentoso, terapia, medidas educacionais e medidas alternativas. Totalizaram seis casos: TDA, TDAH, Síndrome de Irlen, TEA, Dislexia e Ansiedade. Os quatro primeiros casos foram encontrados pessoalmente e gravados pela própria equipe de pesquisa e os dois últimos extraídos de plataforma de vídeo de acesso livre (YouTube).

Transtorno de Déficit de Atenção sem Hiperatividade: a diagnosticada já adulta, relatou ter tido o acompanhamento médico, fazer terapia psicológica, meditação e práticas esportivas como medidas. Com a integração de atividades, ela afirmou ter hoje maior controle sobre suas emoções e maior gerenciamento do tempo de estudo, que era um fator agravante para um bom desempenho nos estudos. Sua melhora e o sucesso educacional resultaram na conclusão de duas 
graduações e em ter passado em dois concursos públicos. Vídeo de 9’01”.

TEA: o diagnosticado teve estratégias lúdicas desenvolvidas por ele e pela família para aprender melhor. Construção de alfabetos com materiais alternativos e "caixinha da memória" são alguns exemplos. O menino anotava o que havia aprendido e guardava numa caixinha para ter onde acessar caso esquecesse. Além disso, teve acompanhamento de terapia psicológica e fez uso de medicação para o quadro epiléptico que possuía. Hoje jovem, ainda conta com o apoio materno na busca constante de artifícios que contribuam com seu desenvolvimento. Melhor memorização, melhor relação professor-estudante e melhor desenvoltura em expor dúvidas em sala de aula, foram alguns dos resultados que obteve. O sucesso foi medido pela conclusão do ensino fundamental e médio, frequência em ensino técnico e domínio da tecnologia, inclusive com a gestão de um canal do Youtube, no qual o participante fala sobre jogos. Vídeo de 16’30”.

Transtorno de Déficit de Atenção e Hiperatividade: a participante do vídeo, atualmente na fase de adolescência, também contou com o apoio incansável da família, que recorreu às mais diversas medidas. Além do quadro de TDAH, a menina apresentava gagueira, que gerava insegurança, que acarretava em timidez, que influenciava na desenvoltura escolar. Ainda criança, foi submetida a medicação, fonoaudióloga, psicopedagoga e terapia psicológica. Mas, aqui o diferencial foi a conduta docente da professora do Fundamental I, que não mediu esforços para aplicar estratégias de ensino de acordo com o problema. Ela ofertou jogos de alfabetização; se atentou onde a menina se sentava; se tentou às orientações que eram transmitidas; passou a dar apoio nas leituras de textos e provas, lendo junto com a aluna. Em paralelo, a escola forneceu o reforço escolar de matemática individualizado, com uma professora que também desenvolveu estratégias específicas. Com o conjunto de intervenções, a menina teve uma significativa e visível melhora, apresentando um bom desempenho escolar, com boas notas, maior socialização e comunicação. Vídeo de 17'30’.

Síndrome de Irlen: a diagnosticada, ainda criança, teve duas intervenções que foram fundamentais no seu desempenho. A menina, que apresentava dificuldades matemáticas e grande desinteresse pela leitura, recebeu aulas particulares de matemática, onde houve grande empenho docente em aplicar estratégias lúdicas e associadas à vida real, para que a aluna aprendesse além das contas, mas para que desenvolvesse também o raciocínio lógico. Além das medidas de ensino, ela teve acesso a um recurso específico do diagnóstico, as Overlays, que neste caso, era no formato de régua e na coloração lilás. A cor foi escolhida por ela mesma na fase dos testes e a dinâmica da régua é ser colocada em cima da linha do material que está lendo. A profissional que a diagnosticou, relatou que, parte da problemática em ciências exatas era 
Formação Continuada De Professores E O Uso De Vídeos-Relatos: Construção E Avaliação De Uma Intervenção

pela má interpretação de textos, que surgia devido à dificuldade de leitura que o problema gerava. Após as estratégias, os resultados obtidos foram melhor desempenho escolar, com boas notas e interesse pela leitura. Vídeo de 17'21'.

Ansiedade Generalizada: a terapia psicológica foi relatada como a principal intervenção, onde aprendeu diversos artifícios para amenizar os sintomas. No vídeo, ela confirma a melhora no desempenho e repassa algumas dicas, que incluem: exercícios físicos diários, assistir vídeos de relatos de pessoas que superaram o problema, técnicas de respiração, mudança na alimentação, contato com a natureza, evitar ambientes escuros e exposição moderada à luz solar. O sucesso aqui foi a diminuição das crises de ansiedade. Embora não tenha se tratado de estratégias especificamente educacionais, algumas técnicas são aplicáveis no contexto escolar e não oferecem riscos ao estudante. Vídeo de 11'04'.

Dislexia: relatos de dois participantes. Um deles, uma mulher, diagnosticada ainda criança, que teve por intervenções o acompanhamento psicológico, fonoaudiológo e psicopedagógico. Os pais também desenvolveram estratégias para uma melhor qualidade de vida da filha, por exemplo, melhorar a noção espacial, pois se perdia facilmente por trocar os lados. Ela tinha como característica, o desinteresse pela leitura pela dificuldade em ler e compreender ao mesmo tempo. Com isso, passou a desenvolver suas próprias estratégias, como: ler em locais silenciosos; quando necessário ler para outra pessoa, primeiro realizar a leitura para ela mesma em voz baixa e depois reler em voz alta, para a garantia de compreensão; marcar os materiais com grifos e desenhos sobre o que entendeu do conteúdo. O resultado foi adquirir gosto pela leitura e ter hoje uma rotina permanente da prática. $\mathrm{O}$ outro participante, um rapaz, diagnosticado quando jovem, desenvolveu seus próprios caminhos para aprender melhor e ter maior desempenho acadêmico, entre eles, sentar perto do professor, realizar trabalhos em grupo. Percebeu também que, poderia se comunicar por meio da arte, com músicas e desenhos, pois habilidade artística é uma característica do disléxico. Ele usou isso a seu favor, e optou por estudar Artes Gráficas. Por resultados, teve a conclusão do curso e a passagem direta em todas as disciplinas, sem dependências. Vídeo de 16'21',

\subsubsection{Material de leitura}

Foram oferecidos textos como apoio aos vídeos-relatos e para ampliação de conhecimento sobre o tema. O material foi extraído de livros e artigos científicos. O critério de seleção se deu pela relevância da abordagem, compatibilidade entre o assunto e as medidas que os participantes dos vídeos realizaram e pelo renome do (a) autor (a) acerca do assunto. 
Na semana 1 foram os textos: "Por que meditar? A experiência subjetiva da prática de meditação" das autoras Carolina Baptista Menezes e Débora Dalbosco Dell'Aglio e "Inclusão educacional de pessoas com Autismo no Brasil: uma revisão de literatura" dos autores Débora Regina de Paula Nunes, Mariana Queiroz Orrico Azevedo e Carlo Schmidt.

Na semana 2 foram fornecidos trechos do livro a "A Biologia da Crença do autor e Biólogo, Bruce H. Lipton.

1. O "prólogo"; parte do capítulo 2: "É o ambiente, sua besta",

2. e parte do capítulo 5: "Nocebos, o poder da crença negativa".

$\mathrm{Na}$ semana 3 foi o artigo "Habilidades sociais e afetividade no contexto escolar: Perspectivas envolvendo professores e ensino-aprendizagem" das autoras Valéria Teixeira da Cunha Reis, Mary Anne Rodrigues Prata e Adriana Benevides Soares.

\subsubsection{Discussão mediada}

A "Discussão Mediada" foi promovida visando a reflexão; troca de experiências e posicionamento do grupo sobre os temas abordados nos vídeos-relatos e para que fosse um momento também de expor suas percepções.

As perguntas foram pré-estabelecidas pela equipe de pesquisa com o objetivo de proporcionar um momento de exposição de ideias e quuue pudéssemos perceber um pouco de suas percepções. Os resultados da discussão não foram mensurados.

As questões foram foram apresentadas em tópicos em data show para visualização e acompanhamento de todos.

Foram levantados pontos, como:

a) vocês reconhecem os sintomas relatados em algum de seus alunos e alunas?

b) vocês têm alunos e alunas com esse diagnóstico?

c) quais estratégias vocês utilizam com eles?

d) é comum considerar casos como estes "sem solução"?

e) vocês concordam com as intervenções realizadas? O que sugeririam de diferente?

\subsubsection{Tarefa de observação}

A "Tarefa de observação" foi uma atividade que além de ser uma estratégia da 
Formação Continuada De Professores E O Uso De Vídeos-Relatos: Construção E Avaliação De Uma Intervenção

intervenção, foi um instrumento de análise da pesquisa. Nela conteve questões semelhantes as da discussão mediada, a fim de incentivar que os professores observassem seus estudantes com mais atenção e critério em relação aos possíveis sintomas que foram descritos nos vídeos; e conteve sugestões de estratégias a serem aplicadas aos alunos (sem entrar em âmbito médico e terapêutico, garantindo a integridade dos envolvidos), também mencionadas nos vídeos.

A atividade foi impressa e entregue semanalmente à cada participante. A da semana 1 (A) foi recolhida na semana 2; a da semana 2 (B) recolhida na semana 3; a da semana 3 (C) recolhida na mesma semana, pois foi realizada no próprio encontro, portanto, baseada em suposições. A análise qualitativa se deu por meio das respostas dos professores, que relataram entre outras coisas, como se deu a aplicação das estratégias e os efeitos gerados.

A intenção era que por meio da estratégia "vídeos-relatos", os professores fossem telespectadores dos casos reais, e que por meio da "tarefa de observação", fossem sujeitos ativos no processo, colocando em prática o que viram em teoria e exercendo a observação criteriosa em sala de aula.

\subsection{Aplicação da intervenção}

A busca por professores participantes se deu por meio de divulgação nas redes sociais e visitas em escolas, onde o projeto era apresentado à coordenação e repassado aos professores. Para participar da pesquisa, deveria ser professor atuante do ensino básico, ser brasileiro e aceitar a participação voluntária.

O professor que aceitasse participar, deveria passar e concluir três etapas do processo. Pré intervenção: aplicação do questionário por meio da plataforma Google Forms; Intervenção: aplicação da intervenção composta pela quatro estratégias; Pós intervenção: reaplicação do questionário por meio da mesma plataforma. Cada participante foi contemplado com um certificado de participação emitido pela Faculdade de Filosofia, Ciências e Letras de Ribeirão Preto (FFCLRP).

Totalizaram 52 professores concluintes, sendo 47 mulheres e 5 homens. Do total, 42 afirmaram lecionar apenas em escolas públicas. Dessa parcela, 12 possuem ensino superior completo, 28 pós-graduação e 2 pós-doutorado; 6 lecionam só em escola particular e 1 tem o superior completo, enquanto os demais, pós-graduação; e 4 professores lecionam nas duas redes, tendo apenas 1 com superior completo, e os demais, pós-graduação.

A idade dos participantes variou de 25 à 62 anos e o tempo de atuação de 1 a 32 anos. O nível de atuação era Educação Infantil, Ensino Fundamental I, Ensino Fundamental II e Ensino Médio. As rendas variam de 1 a 12 salários mínimos, sendo a maior de quem exerce na 
rede pública e privada. A religião predominante foi o catolicismo, sendo 38 indivíduos católicos, 11 evangélicos, 2 espíritas e 1 sem religião.

Os cursos de formação incluiam: Pedagogia, Matemática, Artes, História, Educação Física, Letras, Ciências Biológicas, Educação Especial e Inclusão, Geografia e Ciências.

Dos 52 participantes, 38 afirmaram ter algum conhecimento sobre genética em comportamento humano e 33 afirmaram ter estudado aspectos da genética, durante a formação para professor.

O formato da intervenção contemplou um curso de formação continuada de professores em modalidade presencial, com duração de três semanas e com a carga horária de 30 horas. A intervenção foi intitulada “Aprender para além da Diagnóstico: uma análise dos casos reais”. Ocorreu em dias de reuniões pedagógicas no mês de agosto de 2018 em cinco escolas de três cidades do estado de São Paulo: Ribeirão Preto, com aproximadamente 700.000 habitantes; Pradópolis com aproximadamente 20.000 habitantes e Pardinho, com aproximadamente 6.000 habitantes. Quatro das escolas eram da rede pública e uma da rede privada.

Foram três aplicadoras do gênero feminino que conduziram a intervenção. Duas com formação em Ciências Biológicas (23 e 34 anos) e uma com formação em Psicologia (25 anos). Cada uma é residente da cidade em que ocorreu a aplicação.

Os resultados de uma mesma "aula" para turmas diferentes nunca são iguais, mas, a fim de manter a integridade da aplicação, na garantia que se cumprisse todas as pautas, foi montado um script para cada encontro, que foi seguido por todas.

Quanto as estratégias, seguimos a mesma dinâmica em todos os encontros: aplicação dos vídeos-relatos, discussão mediada baseada nos vídeos; tarefa de observação e textos complementares. Mas, nas três semanas o curso se iniciou com a entrega de uma lista de presença para o recebimento do certificado. A participação foi efetiva e os que perderam parte ou o encontro todo, se prontificaram a participar com outra turma. A iniciativa foi autorizada e se concretizou com duas professoras.

Na lista da Semana 2, foi acrescentada a pergunta sobre o participante ter lido ou não os textos referentes a Semana 1; na Semana 3 foi mantida esta pergunta e acrescentadas mais duas: "Que nota de 0 a 10 você atribui ao curso?" e "Você gostou do uso de ferramentas tecnológicas?".

Foi sugerida a leitura dos textos em horários alternativos ao curso, devido ao tempo limitado de cada encontro. Para isso, suas cópias foram fornecidas à escola para impressão de quem preferisse e disponibilizadas por e-mails.

$\mathrm{Na}$ Semana 2 foi entregue uma atividade nomeada como "Estudo dirigido", contendo 
Formação Continuada De Professores E O Uso De Vídeos-Relatos: Construção E Avaliação De Uma Intervenção

quatro questões sobre os textos dos encontros realizados (não incluiu o da semana 3), na qual deveria ser respondida e devolvida às aplicadoras na semana seguinte. A atividade não foi considerada uma intervenção propriamente dita e as respostas não foram avaliadas como certas ou erradas.

\subsection{Análise de resultados}

Os resultados relativos à viabilidade da intervenção foram captados por meio das:

a) respostas dos professores a partir da tarefa de observação atribuída à cada semana.

O instrumento utilizado (Apêndice E) foi composto por dez questões, incluindo as três semanas. Para o estudo foram selecionadas as respostas que atenderam ao objetivo das seguintes questões:

\section{Semana 1:}

Diante do que vimos e discutimos, aplique uma estratégia diferenciada com estes estudantes. Exemplos: ao invés de usar somente as habilidades escritas, solicitar habilidades orais ou desenhos; escolher junto com ele um novo lugar na sala; fazer um elogio; escutá-lo sobre o que o incomoda, entre outras coisas. Depois disso, relate se houve alguma reação/efeito, seja positivo ou negativo.

\section{Semana 2}

Diante do que vimos e discutimos, aplique uma estratégia diferenciada com estes estudantes (com Hiperatividade ou Síndrome de Irlen). Descreva-a e relate se houve algum efeito, seja positivo ou negativo.

\section{$\underline{\text { Semana } 3}$}

Na suspeita do estudante ter um destes distúrbios, acha que teria um olhar diferenciado para detectá-los? Faria o que para "concluir" algo ou para ajudá-lo?

Se for para escolher uma estratégia para melhorar a ansiedade do estudante ou para melhorar a condição de dislexia, qual seria? Aplique uma para cada distúrbio e relate como se fosse colocar em prática. Desafio: Colocar em prática.

Percepções docentes sobre as influências genéticas e ambientais nos domínios Dificuldades de aprendizagem e Doenças mentais.

Os itens da avaliação das percepções de professores se deram por meio de um questionário (Anexo 1) sobre influências genéticas e ambientais nos comportamentos relevantes 
no processo educacional (Antonelli-Ponti, Versuti e Silva, 2018) aplicado antes e depois da intervenção. O instrumento é original do Reino Unido e foi utilizado por Walker e Plomin (2005) e já tinha sido adaptado por pesquisadores brasileiros e aplicado no Brasil em 2016 (Antonelli-Ponti, Versuti e Silva, 2018). Os itens foram apresentados em distribuições de frequências de cada opção de resposta.

Para o estudo foram selecionadas as três seguintes questões:

a) como você acha que as dificuldades de aprendizagem são influenciadas por genes e pelo ambiente?

b) como você acha que as doenças mentais são influenciadas por genes e pelo ambiente?

As opções de resposta são as seguintes para as duas questões:

1. Somente genes

2. Mais genes do que ambiente

3. Genes e ambiente em partes iguais

4. Mais ambiente do que genes

5. Somente ambiente

c) sabendo que um aluno tem uma dificuldade de aprendizagem geneticamente influenciada, isto afetaria o seu método de ensinar e acompanhar o aluno?

As opções de resposta são as seguintes para as duas questões foram:

6. Afetaria completamente

7. Afetaria muito

8. Afetaria em parte

9. Afetaria um pouco

10. Não afetaria

Para as duas primeiras questões, foram atribuídos valores desde 1 'somente genes' até 5 'somente ambiente'. Para a questão sobre o método de instrução e acompanhamento, foram atribuídos valores desde 1 'não afetaria' até 5 'afetaria completamente'.

O efeito da intervenção nestas respostas foi analisado por meio do Teste de Quiquadrado de Independência com Simulação de Monte Carlo pelo programa de análises estatísticas Statistical Package for the Social (SPSS versão 23.0). Em todas as análises 
Formação Continuada De Professores E O Uso De Vídeos-Relatos: Construção E Avaliação De Uma Intervenção

estatísticas foi utilizado o nível de significância de $5 \%(\mathrm{p} \leq 0,05)$.

\section{Resultados}

\subsection{Respostas dos participantes às tarefas de observação e aplicação de estratégias}

Nesta etapa, os professores relataram dimensões da prática de observação realizada, em sala de aula, em relação aos comportamentos de seus estudantes. A partir desta observação, na Semana 1, metade dos participantes relatou aplicar as estratégias propostas pela intervenção.

As respostas selecionadas e apresentadas a seguir, demonstraram tentativas de diversificação e personalização de estratégias docentes com efeitos positivos sobre os estudantes na percepção do professor.

Estratégias sugeridas na Semana 1: solicitar habilidades orais ou desenhos; escolher junto com o estudante um novo lugar para sentar; fazer um elogio; escutá- lo sobre o que o incomoda; estratégias sugeridas no vídeo: meditação, terapia, esportes.

Uma professora que leciona para dois estudantes com TDAH, afirma:

"Eles sentam em lugares distantes de colegas que tiram atenção ou atrapalham a concentração. Participam bastante da aula através da oralidade e realizam atividades diferenciadas com exercícios de memorização dos conteúdos e figuras."

Outra professora relata que possui em torno de 10 estudantes com TDA e afirma:

"Tenho mudado de lugares esses estudantes com sintomas de TDA e TDAH; converso individualizado com eles, peço que falem o que estão sentindo, o que querem e esperam da escola e de nós, professores. Percebo que o diálogo com eles, ouvindo o que sentem, melhora o relacionamento com a gente e com a disciplina."

Outra professora relata a forma como abordou um estudante:

“Apresentei alguns desenhos relacionados aos conteúdos trabalhados e o estudante respondeu corretamente. Junto com ele escolhemos um novo lugar, no qual se adaptou e se sentiu confortável. Estou sempre elogiando e motivando e percebo que fica feliz. Não gosta de barulho e de ser interrompido."

E esta fala sobre uma tentativa de estratégia para toda a turma: 
“Apliquei uma técnica de meditação com música no $8^{\circ} \mathrm{A}$ e $7^{\circ} \mathrm{A}$. Embora não tenha tido engajamento de todos (o que foi respeitado), depois da prática eles ficaram mais calmos e aumentou a concentração na atividade.

Apliquei uma atividade de matemática e solicitei que o estudante fosse na lousa explicar como ele havia resolvido. Ele se sentiu capaz, percebi que sua autoestima melhorou."

$\mathrm{Na}$ Semana 2, aproximadamente 30\% dos professores relataram aplicar as estratégias (atividades lúdicas, uso de régua para leitura, impressões coloridas, motivação, habilidades orais):

"Eu usei elogios como forma de encorajamento, mas demonstrei firmeza quando pedi para que eles se esforçassem para realizar as atividades propostas. Os estudantes demonstraram que necessitam de organização, encorajamento e disciplina. A maioria reagiu de maneira positiva, sentindo prazer em ser elogiado e querendo mais.

A única ação que consegui pôr em prática foi aconselhar os estudantes a usarem régua na leitura de textos.

Uma atividade que sempre é positiva é quando eu peço a esse estudante para ajudar uma aluna que tem muita dificuldade. Ele se sente útil e aprende.”

Uma professora na suspeita do estudante ter Síndrome de Irlen, afirma:

"Tenho tentado algumas estratégias, como: não colocá-lo de frente com a janela, fechar bem as cortinas, imprimir atividades em papel colorido, repartir o quadro em colunas, esperar um tempo maior para realizar a cópia da matéria, pedir para usar a régua para marcar o texto na hora da leitura. Observei que ele ficou mais calmo e já conseguiu fazer as atividades da semana, ainda que, mais lento que os outros. Ele disse que ficou muito feliz em conseguir fazer tudo.”

Outra professora na suspeita do estudante ser hiperativo, afirma:

"O estudante recebeu duas folhas, uma com gravura de uma história, a outra com o texto fatiado, tinha que pintar, recortar e relacionar a escrita à gravura. $\mathrm{O}$ estudante montou a história com autonomia e leu, já está lendo palavras e frases, pois venho trabalhando com atividades diferenciadas desde o começo do ano e os resultados são positivos, tanto no processo ensino e aprendizagem e como lidar com o comportamento."

Na Semana 3, 82\% dos professores participantes relataram que aplicariam estratégias sugeridas pelo curso. Estratégias sugeridas: técnicas de respiração, contato com a natureza, explorar outras habilidades do estudante, cooperação.

"Para ansiedade usaria a estratégia da respiração na concha. Pediria para que os estudantes se acalmassem, respirassem na concha e explicaria o porquê dessa atividade. Faria 
Formação Continuada De Professores E O Uso De Vídeos-Relatos: Construção E Avaliação De Uma Intervenção

a respiração de concha como sugerido pelo vídeo. No caso da ansiedade é muito importante o professor passar confiança e acreditar que o estudante é capaz de realizar a atividade proposta, seja uma avaliação ou uma apresentação para a sala. Já no caso da dislexia, o procedimento para que se possa avaliar o estudante seria na oralidade. Mesmo entregando uma avaliação para ele responder, sempre na hora da correção deve-se chamar o estudante e pedir para que ele leia sua resposta.

Além de estudar melhor sobre o caso, buscaria estimular o estudante e adequar minhas aulas da melhor forma possível para ajudá-lo a se desenvolver, como por exemplo: oferecer atividades lúdicas, musicalização, leitura, montagem de alfabeto, atividades externas, como, visitas a museus, parques, etc."

\subsection{Resultados das percepções docentes sobre comportamentos relevantes no ambiente educacional}

Os principais achados obtidos foram:

a) maiores frequências de respostas sobre a influência de genes e ambiente nas dificuldades de aprendizagem foram "genes e ambiente em partes iguais (3)", "mais genes do que ambiente (2)" e "mais ambiente do que genes (4)", respectivamente. A frequência de respostas para "somente genes (1)" foi a mais baixa e não houve respostas para "somente ambiente (5)". Após a intervenção a sequência se manteve, porém, houve diminuição nos itens 2 e 3, e aumento nos itens 1 e 4 . Esta diferença é estatisticamente significativa (Tabela 1);

b) maiores frequências de respostas sobre a influência de genes e ambiente nas doenças mentais foram "mais genes do que ambiente (2)", "somente genes (1)" e "genes e ambiente em partes iguais (3)", não houve respostas para "mais ambiente do que genes (4)" ou "somente ambiente (5)". Após a intervenção a sequência se manteve, porém, houve diminuição nos itens 3 e 4 e aumento da frequência de respostas no item 1. A diferença, no entanto, não é significativa (Tabela1);

c) as frequências de respostas dos professores sobre como ter um estudante com dificuldade de aprendizagem geneticamente influenciada afetaria seu método de instruir: "afetaria em parte (3)", "afetaria muito (4)", "não afetaria (1)" e "afetaria completamente (5)" apresentaram as mesmas frequências, e "afetaria um pouco (2)" foi a menor frequência. Após a intervenção a frequência 3 diminui, 2, 4 e 5 aumentam e a frequência do item 1 não se altera. As diferenças apresentadas são estatisticamente significativas (Tabela 2). 
Tabela 1 - Porcentagem de percepção dos professores sobre as influências genéticas e ambientais nos domínios Dificuldades de aprendizagem e Doenças mentais na pré e pós intervenção, com indicação do possível efeito da intervenção pelo teste Qui quadrado $(n=52)$.

\begin{tabular}{|c|c|c|c|c|c|c|}
\hline Domínio & Condição & (1) & (2) & (3) & (4) & (5) \\
\hline \multicolumn{7}{|c|}{ Dificuldades de Aprendizagem } \\
\hline & Pré & $3,8 \%$ & $32,7 \%$ & $42,3 \%$ & $21,2 \%$ & $0,0 \%$ \\
\hline$\chi^{2}=55,121(\mathrm{df}=9) \mathrm{p}<0,05$ & Pós & $7,7 \%$ & $30,8 \%$ & $38,5 \%$ & $23,1 \%$ & $0,0 \%$ \\
\hline \multicolumn{7}{|l|}{ Doenças mentais } \\
\hline \multirow[b]{2}{*}{$\chi^{2}=8,778(d f=9) p<0,187$} & Pré & $30,8 \%$ & $46,2 \%$ & $23,1 \%$ & $0,0 \%$ & $0,0 \%$ \\
\hline & Pós & $32,7 \%$ & $46,2 \%$ & $11,5 \%$ & $9,6 \%$ & $0,0 \%$ \\
\hline
\end{tabular}

Legenda: (1) somente genes; (2) mais genes do que ambiente; (3) genes e ambiente em partes iguais;

(4) mais ambiente do que genes; (5) somente ambiente.

Fonte: a autora

Tabela 2 - Porcentagem de percepção dos professores sobre seu método de instruir e acompanhar um estudante com dificuldade de aprendizagem geneticamente influenciada na pré e pós intervenção, com indicação do possível efeito da intervenção pelo teste qui quadrado (n-52).

\begin{tabular}{llrlllll}
\hline Método de instruir & Condição & (1) & (2) & (3) & (4) & (5) \\
\hline \multirow{2}{*}{$\chi 2=72,513(\mathrm{df}=16) \mathrm{p}<0,05$} & Pré & $11,5 \%$ & $7,7 \%$ & $40,4 \%$ & $28,8 \%$ & $11,5 \%$ \\
& Pós & $11,5 \%$ & $9,6 \%$ & $34,6 \%$ & $30,8 \%$ & $13,5 \%$ \\
\hline
\end{tabular}

Legenda: (1) não afetaria; (2) afetaria um pouco; (3) afetaria em parte; (4) afetaria muito; (5) afetaria completamente.

Fonte: a autora

\section{Discussão}

\subsection{As estratégias da intervenção}

A intervenção foi proposta com objetivo de incentivar uma observação cuidadosa do professor em relação ao estudante e, a partir dos casos reais incentivar ao uso de estratégias docentes favoráveis à aprendizagem significativa do estudante, sendo suas percepções o ponto de partida para uma apropriada atuação. Em concordância, seguiu o estudo de Silva e Souza et al (2018), onde aplicaram uma capacitação para 4 estudantes de Pedagogia e 1 Pedagoga atuante, com o intuito de agir nas atitudes em relação à inclusão de estudantes com deficiência. Os resultados foram positivos e sugerem que uma intervenção de quatro horas já é suficiente para mudar as condutas educacionais. A intervenção da atual pesquisa teve duração de 30 horas considerando os encontros, atividades de observação, aplicação de estratégias, leitura de materiais e preenchimento das atividades e questionários. Os componentes da intervenção 
Formação Continuada De Professores E O Uso De Vídeos-Relatos: Construção E Avaliação De Uma Intervenção

foram organizados de forma que um complementasse o outro e os participantes adquirissem conhecimento de maneira teórica, ilustrativa e tivessem condições de colocar em prática o que aprenderam.

Os vídeos-relatos foram a estratégia de destaque, pois o uso de um material audiovisual vai ao encontro com a atualidade, caracterizando uma TDIC, que atuou como mediador tecnológico da intervenção. Apesar de já em outras décadas ter se começado a pensar no uso de vídeos no meio escolar (Cabral e Rodrigues, 2016) e de haver uma evidente percepção docente sobre a significância do uso de vídeos na aprendizagem (Cinelli, 2003), o feito garante uma característica moderna diante dos avanços de comunicação. As Tecnologias Digitais da Informação e Comunicação devem compor as medidas educacionais, porque são relevantes no processo de instrução e porque junto com a modificação do homem pelas novas tecnologias, veio a necessidade de novas competências e formações (Martins, 2010; Pinheiro, 2016; Rosa e Cecílio, 2010).

Além de passar informação e ser de fácil acesso, os vídeos, por si só, são capazes de atrair e prender a atenção de quem os assiste; ilustrar o que muitas vezes é visto somente na teoria; atuar nas crenças e emoções do indivíduo e até de mudar comportamentos, percepções e atitudes (Bernard et al, 2015; Cinelli, 2003; Lima, et al, 2019; Martins, 2010). Corroboram com essa afirmação alguns relatos que selecionamos dos participantes, como:

"Faria a respiração de concha como sugerido pelo vídeo. Através dos vídeos assistidos fica mais fácil perceber que alguns estudantes possam apresentar algum distúrbio.”

No estudo de Bernard et al. (2015) e Hilbert (2016), é possível ver que a aplicação de vídeos é usada como fim interventivo em várias partes do mundo: uma ONG na Índia toma essa prática com foco em conteúdos agronômicos para motivar os agricultores da região; um Projeto na África do Sul recruta candidatos de classe baixa indo pessoalmente em suas casas e mostrando vídeos de empreendedores que tiveram sucesso; pesquisadores na Alemanha usaram o recurso para quebrar estigmas relacionados à obesidade; no Brasil (Andrade e Barbosa, 2016) analisaram concepções acerca da equidade de gênero por meio de um vídeo, e ainda sugerem que o mesmo seja objeto em formações docentes, nas quais tenham como foco o uso das TIC's nas escolas. Estudos de diferentes anos (Cabral e Rodrigues, 2016; Martins, 2010; Miranda, 2007), apontam que a falta de capacitação para o uso de recursos modernos em sala de aula e sua adequada aplicação tem sido uma queixa do próprio público docente, pois os professores 
devem conseguir cada vez mais usar as TIC's como ferramentas aliadas no ensino; se encaixar na dinamicidade que as tecnologias têm proporcionado e se alinhar com as práticas atuais dos estudantes.

O uso de vídeos em intervenções para formação de profissionais também é uma prática que já tem sido concretizada, demonstrado no estudo de Lima et al. (2019). Os estudantes de medicina que participaram do processo, afirmaram que a prática trouxe muitos efeitos positivos. Muitos indicam o uso de vídeos como recurso pedagógico e todos consideraram uma estratégia atrativa. Essas informações foram obtidas por meio de um questionário eletrônico.

A aplicação e análise de filme compôs uma das estratégias de formação continuada para professores no Brasil voltada ao Ensino Experimental de Física. Totalizando quatorze encontros de quatro horas e treze professores participantes, pode-se dizer, que a formação com todas suas medidas, trouxe mudanças nas concepções e práticas docentes (Coelho e Nunes, 2008). A estratégia fez parte também de uma formação pedagógica continuada realizada para 32 professores universitários (Junges e Behrens, 2015), que ocorreu em dez encontros uma vez ao mês e que teve como objetivos promover reflexão sobre a atuação docente e agir na percepção sobre suas práticas. Numa característica tecnológica, também fez parte fóruns online, além de estratégias mais tradicionais, como material de leitura.

O uso de textos é uma prática eficiente para a aquisição de conhecimento e se faz como ferramenta muito habitual no ambiente escolar, são os principais meios de se estudar conteúdos. A linguagem é a ponte para o aprendizado, sendo a escrita e a leitura seus eixos, os materiais de leitura tornam-se essenciais nos processos educativos e na formação do indivíduo, com capacidade de modificar pensamentos, percepções e comportamentos (Costa e Sousa, 2015). O mundo é letrado e diariamente somos submetidos aos diferentes meios de leitura: jornais, revistas, manuais, livros, artigos, panfletos, cartas, o que torna a utilização de textos um recurso de fácil acesso. Por tudo isso, material de leitura também compôs a intervenção, de modo que desse aporte aos vídeos, contendo informações científicas e dados confiáveis, ao mesmo tempo em que fosse de linguagem clara para atingir a compreensão de todos.

A entrega da atividade sobre os textos foi o marcador da tarefa, mas não serviu como garantia total da realização, já que uma limitação do estudo foi a sugestão de leitura fora dos encontros, devido ao tempo limitado. Diferente dos vídeos, que além da certeza da participação de quem estava presente, o material apresentou potencial, pois recrutamos seis casos reais com propostas de estratégias diferentes, parte delas podendo ser aplicadas no ambiente escolar. Depoimentos de superação e de afetividade, também fizeram parte do conteúdo dos vídeos. O afeto, não só posto como importante fator na relação professor-aluno (Leite, 2012), foi dado 
Formação Continuada De Professores E O Uso De Vídeos-Relatos: Construção E Avaliação De Uma Intervenção

por meio das tarefas de observação como uma estratégia aplicável e eficiente. Uma simples conversa, interesse em saber o que o aluno quer aprender, atenção ao problema, um elogio, pode ser uma grande demonstração de afeto.

Assim, como os resultados da atual pesquisa, Junges e Behrens (2015), concluíram que a formação foi positiva nas condutas docentes, pois passaram a adequar os métodos de ensino e de avaliação, levando em conta a experiência de vida do estudante e entendendo que é a partir das próprias concepções educacionais que a mudança começa. O artifício formativo que proporcionou isso tudo foram relatos de experiência, que também gerou troca e conhecimentos. As estratégias podem ter a mesma finalidade, embora com atribuições diferentes, "troca de experiências" (Bolzan et al., 2013); "reflexões" (Coelho e Nunes, 2008; Junges e Behrens, 2015); “discussões” (Coelho e Nunes, 2008); “prática reflexiva” (Silva e Araújo, 2005), nós chamamos de "Discussão mediada". A "Discussão mediada" é facilmente aplicada e é de tamanha serventia, o que a faz ser usada em diferentes situações: aulas, grupos de pesquisa, cursos e formações. A estratégia foi promovida no sentido de ressaltar a interação entre indivíduo e o meio; e a maleabilidade dos traços e mudanças até e condições geneticamente influenciadas.

No Brasil, usaram da "prática reflexiva" para sugerirem a própria "prática reflexiva" e “troca de experiências" como estratégias de formação docente (Bolzan et al., 2013), o que vai ao encontro com a colocação de Silva e Araújo (2005), que apontam a necessidade dessas ações num formato adequado de formação continuada de professores. Se bem planejada e levada a sério pelos participantes, os resultados podem ser bastante positivos e nossas concepções serem percebidas pelos outros e por nós mesmos, o que muitas vezes ocorre apenas com a troca e exposição de ideias. Bicalho e Oliveira (2012) corroboram que a troca, a socialização e o diálogo são importantes na aprendizagem, e que, embora o professor esteja numa posição de maior responsabilidade em relação aos outros, todos os interlocutores são ativos no processo.

A “Tarefa de observação" foi uma estratégia que oportunizou praticar o que foi discutido em teoria durante o curso e trocar as vivências entre os participantes. É uma prática bastante explorada em estudos de Etologia e de Psicologia e seu uso nessa pesquisa foi inspirado em observações de casos reais (Seidl-de-Moura et al., 2004; Sevilha e Bussab, 2015). A prática de observação é simples e aplicável, pois não requer grandes recursos. Por meio dela, os professores são incentivados a olhar criteriosamente para os estudantes, seus métodos e condutas em sala de aula. A tarefa propôs que os professores tentassem detectar a presença de estudantes com as condições e dificuldades contempladas nos vídeos-relatos, que refletissem o quão estes estudantes estão tendo acesso às estratégias educacionais, que aplicassem algumas 
medidas que trouxeram bons resultados no desempenho dos participantes dos vídeos e que julgassem seus efeitos. Foram propostas medidas pertinentes no âmbito escolar, sem invadir âmbitos médicos e terapêuticos, garantindo a integridade do indivíduo. Uma sugestão foi conduzir os estudantes a técnicas de respiração usadas na meditação, pois estudos apontam os efeitos positivos dessa prática no desempenho escolar/acadêmico, trazendo melhora em alguns aspectos que impactam no processo de aprendizagem, como o aumento de concentração e a diminuição de ansiedade (Vascouto et al., 2013).

$\mathrm{Na}$ mesma tentativa de integrar estratégias interventivas, o estudo de Coelho e Nunes (2008) propõe uma formação para o ensino de Física com: reflexões sobre as práticas e conhecimentos docentes; discussão mediada; análise de textos e vídeos. O foco da intervenção foi oficinas com experimentos a partir de protótipos criados com materiais acessíveis. Treze professores participaram da formação, levaram os desafios para sala de aula e depois compartilharam as experiências por relatos e relatórios.

O estudo de Brandt e Moretti (2016) também teve por objetivo uma formação docente voltada aos licenciados em matemática, frente as dificuldades de aprendizagem que os estudantes possuem na disciplina, que pode ter como um dos motivos a falha nas ações didáticopedagógicas. Foram realizados 8 encontros de 8 horas com 23 professores, que se basearam em abordagem teórica de assuntos específicos e discussões de pesquisas sobre as dificuldades das crianças. Também elaboraram atividades para aplicar em sala, que consistia na parte prática da formação. No final do curso, os participantes entregaram um "Estudo de Caso" acompanhado de um relatório sobre 1 estudante e sua mudança de desempenho.

Os casos reais de indivíduos mesmo que com condição geneticamente influenciada, demonstraram superar tais condições e ter melhorado o desempenho pessoal e acadêmico, demonstrando ação positiva das estratégias multiprofissionais.

A demonstração de casos reais em cursos de formação continuada não é comum. Normalmente, os cursos voltados para professores utilizam-se mais de teorias e sugestões de práticas (Brandt e Moretti, 2016; Coelho e Nunes, 2018; Filipin et al., 2016). Embora, estudos de outras áreas utilizem do método (Bernard et al. 2014; Bernard et al. 2015; Lima et al., 2019), o curso apresentado neste estudo pode ser inovador para a área.

\subsection{Viabilidade da intervenção}

\subsubsection{Relatos docentes e realização das atividades propostas na intervenção}

Os resultados qualitativos são positivos no que se refere à viabilidade da intervenção, 
Formação Continuada De Professores E O Uso De Vídeos-Relatos: Construção E Avaliação De Uma Intervenção

pois alguns relatos da "Tarefa de observação" apontam o efeito da intervenção nas condutas docentes em favor à aprendizagem do estudante. Aqui, é possível ver também por meio de relatos, fatores que justificam alguns dados e a percepção que os professores tiveram do curso.

Houve uma queda ao uso de estratégias propostas por meio da "Tarefa de observação" da Semana 2 em relação a Semana 1 (de 50\% para 30\%). Esta diminuição pode ser explicada pela configuração das instituições participantes, como relatado por alguns professores:

“Tentamos trabalhar diferenciado com todos, porém, a superlotação das salas dificulta esse tipo de atendimento."

"Não consegui cumprir essa atividade por conta do curto prazo e cumprimento do currículo."

Na Semana 3, a "Tarefa de observação" consistiu em suposições por ser o último dia do curso e não ser possível a entrega posterior. Dos 52 professores, $82 \%$ afirmaram que aplicariam as estratégias. A parcela que faltou para completar $100 \%$ não respondeu ou não apresentou coerências nas respostas.

$\mathrm{Na}$ mesma tarefa, perguntamos se o participante consideraria ter agora "um olhar diferenciado" para detectar os distúrbios abordados na intervenção. Dos 52 professores, 63\% afirmaram que sim. A partir de suas próprias percepções, duas professores relataram:

"Eu acho que agora, depois do curso, é possível ter um olhar diferenciado para detectar alguns distúrbios. Para concluir algo ou para ajudar o estudante seria através da observação.”

"Através dos vídeos assistidos fica mais fácil perceber que alguns estudantes possam apresentar algum distúrbio, e a partir daí encaminhá-lo para profissionais adequados a realizar testes e fechar o diagnóstico."

A parcela que faltou para completar $100 \%$ não respondeu ou respondeu honestamente, como afirma essa professora:

"Teria que me aperfeiçoar mais, ler, buscar diferenciar o normal do patológico."

"Ficaria complicado para concluir algo, pois não temos esse entendimento para isso, mas buscaria informações para que levasse a uma conclusão sobre o problema.”

Dos 52 participantes, $65 \%$ realizaram a atividade atribuída relacionada ao material de leitura, demonstrando portanto, que leram os textos. Alguns dos que afirmaram não ter lido, 
justificaram a não realização por falta de tempo.

As notas atribuidas ao curso foram de 8 à 10 (sendo as opções de 0 à 10), em sua maioria nota máxima. Apesar da não solicitação de justificativa, uma participante que atribuiu nota 8 , acrescentou:

"Poderia ter sido 10 se eu tivesse me dedicado mais."

As respostas da pergunta sobre o uso de ferramentas tecnológicas foi unânime, todos afirmaram que gostaram. Os dados corroboram com os recolhidos por Lima et al (2019), mais precisamente sobre o uso de vídeos em sala de aula, nos quais apontam unanimidade entre os 16 participantes sobre considerar uma estratégia atrativa.

Os efeitos da intervenção parecem ir além da construção e aplicação das estratégias. Há muitos fatores envolvidos na efetividade da intervenção, como: comprometimento e dedicação do participante; tempo limitado do professor; prazos para entrega das atividades; condições escolares; quantidade de alunos nas salas de aula.

\subsubsection{Percepções docentes sobre comportamentos relevantes no ambiente educacional}

No que se refere às "Dificuldades de Aprendizagem", há uma predominância de frequência no item que representa uma percepção equilibrada na "pré intervenção" e na "pós intervenção", apesar de uma queda no segundo momento; a frequência do item que representa maior influência genética também teve uma queda; houve uma migração para o item que representa determinismo genético ao mesmo tempo em que houve uma migração para o item que representa maior influência ambiental. Os resultados estatísticos apontaram que houve diferença entre os dois momentos.

No que se refere "Doenças Mentais", há uma predominância de frequência no item que representa maior influência genética, que se manteve percentualmente igual no segundo momentos; a segunda maior frequência está no item que representa determinismo genético, que aumentou ainda mais no segundo momento; houve uma queda de frequência no item que

representa uma percepção equilibrada, mas houve um aumento de frequência no item que representa maior influência ambiental. Os resultados estatísticos apontaram que não houve diferença.

Apesar de termos trabalhado os dois domínios do comportamento, a intervenção focou nas dificuldades de aprendizagem e tratou como consequência de outros problemas, decorrente 
Formação Continuada De Professores E O Uso De Vídeos-Relatos: Construção E Avaliação De Uma Intervenção

de sintomas que afetam o processo de aprender. Isso pode justificar a significância estatística da diferença nas percepções sobre dificuldades de aprendizagem e não na percepção sobre doenças mentais.

Os resultados corroboram com um estudo aplicado no Brasil para 501 professores (Antonelli-Ponti, 2018), que apesar da discrepância das amostras, investigou também as percepções docentes sobre os mesmos domínios do comportamento. Para dificuldades de aprendizagem, houve maior representatividade na percepção equilibrada em relação as influências genética e ambiental; e para doenças mentais, a maior representatividade foi na percepção de maior influência genética. Embora não haja predominância de percepções deterministas, os dados não escondem as relevantes frequências nas percepções voltadas a maior influência genética para os dois domínios.

O método de instruir, que antes do curso teve as frequências concentradas em 'afetaria em parte', após o curso apresenta maior distribuição destas frequências, com aumento nas respostas 'afetaria muito', 'afetaria completamente' e 'afetaria um pouco', porém sem mudança na frequência de 'não afetaria'. Estes resultados são diferentes de Antonelli-Ponti et al. (2018) e Walker e Plomin (2005), os quais, com amostras maiores apresentaram menores frequências de professores relatando que não teriam seu método de ensino afetado diante de um estudante com dificuldade de aprendizagem geneticamente influenciada. Vale ressaltar que o tipo de análise escolhida para este estudo buscou verificar as frequências de respostas para cada opção possível. Análises considerando as médias do grupo podem revelar resultados diferentes, o que também pode acontecer com um aumento da amostra com o presente delineamento. Estes aspectos são considerados uma limitação do trabalho. Estudos futuros, no entanto, pretendem contemplar tais análises.

As percepções dos professores vinculadas à atribuição de determinantes genéticos, podem ser oriundas da própria disseminação de conhecimento que se dá ao longo da vida pelo acesso a materiais específicos, formações, cursos de graduação. A quantidade de professores que afirmaram na pesquisa ter algum conhecimento ou estudado aspectos da genética, corrobora com a ideia.

Sobre as percepções para a influência ambiental, houve um aumento tanto para Dificuldades de aprendizagem como para Doenças mentais, o que pode ser um indicativo do efeito da intervenção, que muito deu importância aos fatores ambientais sobre o comportamento. Assim sendo, evidencia-se a relevância de investigar percepções docentes, frente as influências que exercem m nossa vida e na tomada de decisão para com outros (Antonelli- Ponti, Versuti e Silva, 2018). A decisão pode ser investir ou não numa estratégia de 
ensino dentro de uma sala de aula, seja para a atender a necessidade de um estudante ou de todos. O enfoque do atual estudo foi nas dificuldades de aprendizagem, contudo, há preocupação sobre situações inversas, em que o estudante possui capacidades superiores, as quais também exigem estratégias específicas, como é o caso da superdotação (Maia-Pinto e Fleith, 2002).

Percepções sobre as influências nas dificuldades de aprendizagem teve a frequência para determinismo genético aumentada. Essa mudança, pode sugerir uma confusão dos participantes em relação a maneira como os domínios foram abordados na pesquisa, indicando uma limitação do estudo. Em alguns vídeos-relatos, foi falado de origem genética e de inexistente cura do problema, contudo, ao longo da intervenção, o foco foi na melhora do desempenho por medidas que os participantes dos vídeos fizeram, a fim de evidenciar o poder do ambiente e motivá-los na aplicação de estratégias educacionais. O que demonstra uma fragilidade de estudo. De qualquer forma, ao mesmo tempo que aumentaram as percepções relacionadas à maior influência genética, aumentaram também as frequências de professores que teriam seu método de instruir afetado ao saber da dificuldade geneticamente influenciada de um estudante. Neste sentido, o resultado é promissor ao encontrar que mesmo diante de informações que indicam influência genética, estas não parecem indicar determinismo ou ausência de investimento do professor no estudante.

Reconhece-se demais limitações do estudo, a fim de serem reavaliadas para futuras aplicações. Por não se tratar de um ambiente totalmente controlado, houveram situações que podem ter interferido nos resultados, como: atraso dos professores, saídas antecipadas e interrupções. A intervenção ocorreu em escolas do ensino público e particular (não foi realizada análise comparativa entre essas diferenças). Foram três aplicadoras diferentes, que apesar de seguirem um script semanal, possuem suas particularidades na condução. O envolvimento dos professores também foi uma variável, pois nem todos demonstraram total interesse e se dedicaram integralmente. A quantidade de docente que não realizou as atividades pode ser um indicativo disso.

\section{Conclusões}

Conclui-se, que a intervenção se caracterizou como uma proposta de formação continuada de professores adequada aos objetivos delineados, pois tanto os dados qualitativos, por meio dos relatos dos professores, quanto os dados quantitativos, por meio das frequências amostrais, demonstraram eficiência e viabilidade da intervenção.

Além disso, as estratégias elaboradas proporcionaram: troca, vivência em grupo, 
Formação Continuada De Professores E O Uso De Vídeos-Relatos: Construção E Avaliação De Uma Intervenção

reflexões, aquisição de conhecimentos, incentivo à aplicação de estratégias educacionais, mudança de conduta docente. Os vídeos-relatos foram o destaque, pois caracterizou uma TDIC na educação e teve a abordagem de casos reais, levando empatia e motivação aos professores que assistiram.

O estudo também serviu como porta para novos estudos, que com todas as limitações, admite-se que é possível ampliar a aplicação e ter outros focos, como: mudança de crenças e percepções deterministas; quebra de estigmas; proposta de novas medidas educacionais para a comunidade docente; envolvimento de outros públicos.

Levando em conta que, crenças deterministas podem ser prejudiciais para a forma de atuação do professor, o processo permitiu ver as percepções docentes acerca das influências comportamentais sobre dois domínios relevantes no ambiente educacional. A comunidade docente entende que o comportamento humano é regido por forças, independentemente do peso que percebe cada uma. O importante é que não sejam negligenciadas, que cada professor entenda seu papel no contexto das influências ambientais, que esteja disposto a se adaptar às condições do estudante e perceba que cada conduta tem seu valor no desenvolvimento integral do indivíduo.

\section{Referências}

Alves, M. S, Veloso, C. L. S, \& Amorim, S. C. V. S. (2018). Inclusão Escolar de Estudantes com Síndrome de Irlen. Revista Educação, Cultura e Sociedade, 8. Jan/jun.

American Psychiatric Association. (2014). DSM-5 - Manual Diagnóstico e Estatístico de Transtornos Mentais. Porto Alegre: Artmed. (OBS - classificar ordem alfabética)

Andrade, S. J. V. de, \& Barbosa, R. C. (2016). Formação docente para uso das tic: reflexões na perspectiva de trabalhar a temática gênero com o vídeo "Vida Maria" em sala de aula. Simpósio Internacional de Educação à Distância. UFSCar.

Antonelli-Ponti, M., Versuti, F. M., \& Da Silva, J. A. (2018). Teachers' perception about genes and behavior. Estudos de Psicologia (Campinas), 35(4), 421-431. Http://dx.doi.org/10.1590/1982-02752018000400009

Antonelli-Ponti, M. (2016). Percepção de professores sobre a influência genética e ambiental em comportamentos relevantes no processo educacional. Dissertação de Mestrado, Faculdade de Filosofia, Ciências e Letras de Ribeirão Preto, USP, Ribeirão Preto. doi:10.11606/D.59.2016.tde-05052016-071922. Recuperado de www.teses.usp.br

Aquino, R. L. de. (2014, Maio). A inclusão escolar: uma análise sob a ótica de um futuro docente. Simpósio Mineiro de Geografia, Alfenas, Minas Gerais, Brasil. 
Araújo, A. C, \& Neto, F. L. (2014). A Nova Classificação Americana para os Transtornos Mentais - o DSM -5. Revista Brasileira de Terapia Comportamental e Cognitiva, 16 (1), 67-82.

Barcelos, A. M. F. (2004). Crenças sobre aprendizagem de línguas, linguística aplicada e ensino de línguas. Linguagem \& Ensino, 7 (1), 123-156.

Bear, M. F, Connors, B. W, \& Paradiso, M. A. (2008). Neurociências: Desvendando o Sistema Nervoso. (3a. ed): Artmed.

Bejarano, N. R. R., \& Carvalho, N. M. P. de. (2003). Professor de ciências novato, suas crenças e conflitos. Investigações em Ensino de Ciências, 8 (3), 257-280.

Bernard, T., Orkin, K., Dercon, S., \& Taffese, A. S. (Setembro, 2014). The future in mind: aspirations and forward-looking behaviour in rural ethiopia. London: Centre for Economic Policy Research. http://dx.doi.org/10.2139/ssrn.2514590

Bernard, T, Orkin, K, Dercon, S, \& Taffese, A, S. (Janeiro, 2015). Will video kill the radio star? Assessing the potential of targeted exposure to role models through video. The World Bank Economic Review.

Bicalho, R.N.M., \& Oliveira, M.C.S.L. (abr./jun. 2012). O processo dialógico de construção do conhecimento em fóruns de discussão. Interface - Comunicação, Saúde, Educação, 16 (41), 469-83,

Bolzan, D. P. V., Isaia, S. M. A. de, \& Macial, A. M. R. da. (jan/abr. 2013). Formação de professores: a construção da docência e da atividade pedagógica na Educação Superior. Revista Diálogo Educacional, 13 (38), 49-68.

Braga, J. E. F., Pordeus, L. C., Silva, A. T. M. C. da, Pimenta, F. C. F., Diniz, M., F., F., M., \& Almeida, R. N. de. (2010). Ansiedade Patológica: Bases Neurais e Avanços na Abordagem Psicofarmacológica. Revista Brasileira de Ciências da Saúde, 14 (2), 93-100.

Brandt, C. F., \& Moretti, M. T. (2016). Ensinar e aprender matemática: possibilidades para a prática educativa. Ponta Grossa: Editora UEPG.

Brentini, L. C., Brentini, B. C., Araujo, E. C. S., Aros, A. C. S. P. C., \& Aros, M. S. (2018). Transtorno de ansiedade generalizada no contexto clínico e social no âmbito da saúde mental. Nucleus, 15 (1), 237-248.

Bulgraen, V. C. (2010). O papel do professor e sua mediação nos processos de elaboração do conhecimento. Revista Conteúdo, 1 (4), 30-38.

Cabral, Z. A., \& Rodrigues, C. V. (2016). Tecnologia e Sala de Aula: a formação docente em foco. Revista de Ensino, Educação e Ciências Humanas, 17, 491-500.

Ciasca, S. M. (2004). Distúrbios de Aprendizagem: Proposta de Avaliação 
Formação Continuada De Professores E O Uso De Vídeos-Relatos: Construção E Avaliação De Uma Intervenção

Interdisciplinar. São Paulo: Casa do Psicólogo Livraria e Editora Ltda.

Cinelli, F. P. N. (2003). A influência do vídeo no processo de aprendizagem. (Dissertação de mestrado, Engenharia de Produção, Universidade Federal de Santa Catarina). Recuperado de http://repositorio.ufsc.br/xmlui/handle/123456789/85870

Coelho, S. M., \& Nunes, A. D. (Abril, 2008). Formação continuada de professores numa visão construtivista: contextos didáticos, estratégias e formas de aprendizagem no ensino experimental de física. Caderno Brasileiro de Ensino de Física, 25 (1), 7-34.

Cortella, M. S. (2013). Pensar bem nos faz bem. Filosofia, religião, ciência e educação. Vozes Nobilis: São Paulo (5a. ed., vol. 1).

Costa, E. G., \& Nebel, L. (2018). O quanto vale a dor? Estudo sobre a saúde mental de estudantes de pós-graduação no Brasil. Polis Revista Latinoamericana, 17 (50), 207 227.

Costa, M. C., \& Souza, M. A. S. da. (Ago./Dez, 2017). O uso das TICs no processo ensino e aprendizagem na escola alternativa "Lago dos Cisnes". Revista Valore, 2 (2), 220-235.

da Cunha Reis, V. T., Prata, M. A. R., \& Soares, A. B. (2017). Habilidades sociais e afetividade no contexto escolar: perspectivas envolvendo professores e ensinoaprendizagem. Psicologia argumento, 30(69).

Da Silva, E. J. C. (Junho, 2005). Transtornos do déficit de atenção com hiperatividade em adolescentes. Adolescência \& Saúde, 2 (2), 25-29.

de Paula Nunes, D. R., de Azevedo, M. Q. O., \& Schmidt, C. (2013). Inclusão educacional de pessoas com Autismo no Brasil: uma revisão da literatura. Revista Educação Especial, 26(47), 557-572.

de Souza, D. T. R. (2006). Formação continuada de professores e fracasso escolar: problematizando o argumento da incompetência. Educação e Pesquisa, 32 (3), 477492.

Deuschle, V. P., \& Cechella, C. (2009). O déficit em consciência fonológica e sua relação com a dislexia: diagnóstico e intervenção. Revista CEFAC, 11 (2), 194-200.

Faria, L. N. de. (2011). Frequencia da Síndrome de Mares-Irlen entre estudantes com dificuldades de leitura observadas no contexto escolar. (Dissertação de mestrado, Instituto de Ciências Biológicas - UFMG, Belo Horizonte, MG, Brasil). Recuperado de http://www.bibliotecadigital.ufmg.br/dspace/handle/1843/BUOS-962H8G.pdf

Filipin, G. E., Vargas, L. da S. de, Nunes, T. T. G., \& Mello-Carpes, P.M.. (2016). Formação continuada em neuroeducação: percepção de docentes da rede básica de educação sobre a importância da neurociência nos processos educacionais. Revista de extensão universitária de cruz alta, 8 (1), 90-102.

Ferreira, G. C. L., Silveira, P. S. da, Noto, A. R., \& Ronzani, T. M. (2014). Implicações 
da relação entre estigma internalizado e suporte social para a saúde: Uma revisão sistemática da literatura. Estudos de Psicologia, 19 (1), 78.

Franceschini, A. C. T. \& Ferreira, D. C. S. (2012). Economia Comportamental: uma introdução para analistas do comportamento. Interamerican Journal of Psychology, 1 (46), 317-326.

Freeman, D., \& Freeman, J. (2015) Ansiedade: o que é, os principais transtornos e como tratar. (2a. ed.) Porto Alegre: L\&PM Editores.

Gallo, S. "Transversalidade e educação: pensando uma educação nãodisciplinar". In: ALVES, N. e GARCIA, R. L. (orgs.), O sentido da escola. Rio de Janeiro: DP\&A, 1999, pp. 17-41.

Garcia, A. C. O., Momensohn-Santos, T. M., \& Vilhena, D. A. de. (março, 2018). Effects of Spectral Overlays on Reading Performance of Brazilian Elementary School Children. Folia Phoniatrica et Logopaedica, 69 (5-6), 219-225. doi: https://doi.org/10.1159/000484139

Gimenez, E. H. R. (2005). Dificuldade de Aprendizagem ou Distúrbio de Aprendizagem? Revista de Educação, 8 (8), 78-83

Goffman, E. (2004). Estigma: Notas sobre a manipulação da identidade deteriorada. Tradução: Mathias Lambert. Sabotagem, 124p. (Trabalho original publicado em 1963).

Graeff, R. L., \& Vaz, C. E. (Julho/Setembro, 2008). Avaliação e Diagnóstico do Transtorno de Déficit de Atenção e Hiperatividade. Psicologia USP, 19(3), 341361.

Grana, L., \& Bastos, A. G. (2010). Vulnerabilidade social: o psicodiagnóstico como método de mapeamento de doenças mentais Psicologia Ciência e Profissão, 30 (3), 650-661.

Guimarães, M. R. (n.d.). Síndrome de Irlen \& Distúrbios de Processamento Visual pela Via Magnocelular - Por que ler pode ser tão difícil? Fundação Hospital de Olhos Belo Horizonte, MG. Recuperado de: http://fundacaoholhos.com.br/artigos/sindrome-de-irlen- disturbios-deprocessamento-visual-pela-via-magnocelular-por-que-ler-pode-ser-tao- dificil/

Hammil, D. D. (1990). On Defining Learning Desabilities: on emerging consensus: Journal of Learning Desabilities, 23 (2), 74-84.

Hilbert, A. (2016). Weight Stigma Reduction and Genetic Determinism. PLOS ONE, 11 (9), e0162993.

Hora, A, F. et al. (2015). A Prevalência do Transtorno do Déficit de Atenção e Hiperatividade (TDAH): uma revisão de literatura. Revista Psicologia, 29 (2), 47-62. 
Formação Continuada De Professores E O Uso De Vídeos-Relatos: Construção E Avaliação De Uma Intervenção

Imbernón, F. (2010).Formação continuada de professores. Artmed Editora.

Irlen, H., \& Robinson, G. L. (2015). The effect oh Irlen coloured filters on adult perception of workplace performance - A preliminary survey. Australian Journal of Learning Disabilities, 1(3), 7-16.

Jou, G. I. de, Amaral, B., Pavan, C. R., SchaefeR, L. S., \& Zimmer, M. (2010). Transtorno de Déficit de Atenção e Hiperatividade: Um Olhar no Ensino Fundamental. Psicologia: Reflexão e Crítica, 23 (1), 29-36.

Junges, K. S.,\& Behrens, M. A. (jan./abr. 2015). Prática docente no Ensino Superior: a formação pedagógica como mobilizadora de mudança. Perspectiva, 33 (1), 285-317,

Kriss, I., \& Evans, B. J. W. (2005). The relationship between dyslexia and Meares-Irlen Syndrome. Journal of Research in Reading, 28 (3), 350-364.

Leite, S. A. da S. (2012). Afetividade nas práticas pedagógicas. Temas em Psicologia, 20 (2), $355-368$.

Lima V. S., Azevedo N. A. A., Guimarães J. M. X., Pereira M. M., Agostinho Neto, J., Souza,L. M., Pequeno, A. M. C., \& Sousa, M. S. (2019). Produção de vídeo educacional: estratégia de formação docente para o ensino na saúde. Revista Eletrônica de Comunicação, Informação e Inovação em Saúde. 13(2), 428-38.

Lipton, B. H. (2007). A Biologia da crença. Butterfly: São Paulo.

Maia-Pinto, R. R., \& Fleith, D. S. (2002). Percepção de professores sobre alunos superdotados. Estudos de Psicologia Campinas, 19 (1),78-90.

Martins, D. C. R. da. (2010). Tecnologia e educação. O uso da tecnologia na educação como prática pedagógica. (Trabalho de conclusão, Pós Graduação em Mídias Integradas na Educação. Universidade Federal do Paraná, Curitiba).

Menezes, C. B., \& Dell'Aglio, D. D. (2009). Por que meditar?: A experiência subjetiva da prática de meditação. Psicologia em estudo. Maringá. Vol. 14, n. 3 (jul/set 2009), p. $565-573$.

Mercado, L. P. L. (1998). Formação docente e novas tecnologias. IV Congresso RIBIE, Brasília. Universidade Federal de Alagoas, Maceió.

Mercado, L. P. L. (1999). Formação continuada de professores e novas tecnologias. Editora Universitária da Universidade Federal de Alagoas.

Miranda, L., Morais, C., \& Dias, P. (2007). Colaboração em ambientes online na resolução de tarefas de aprendizagem.

Molina, W. F \& Silva, J. da. (2002). Formação de professores para as novas tecnologias. Revista da UNIFEBE, 7 (7), 47-56. 
Moraes, C. de, Silva, F. M. B. N., \& Andrade, E. R. de. (2007). Diagnóstico e tratamento de transtorno bipolar e TDAH na infância: desafios na prática clínica. Jornal Brasileiro de Psiquiatria, 56 (1), 19-24.

Onzi, F. Z., \& Gomes, R. F. (2015). Transtorno do espectro autista: a importância do diagnóstico e reabilitação. Caderno pedagógico, 12 (3), 188-199.

Paula, S. R. de, \& Faria, M. A, de. (2010). Afetividade na aprendizagem. Revista Eletrônica Saberes da Educação, 1 (1).

Pereira, A, P. R. (2017). Escolarização na Educação Infantil: concepções e crenças pessoais sobre aprendizagem e dificuldades de aprendizagem. (Dissertação de mestrado. Instituto de Educação. Universidade do Minho - Braga, Portugal). Recuperado de http://repositorium.sdum.uminho.pt/handle/1822/45683.pdf

Pinheiro, L, B, A. de. (2016). Tecnologia articulada à formação de professores para a educação profissional. Revista de Estudos e Pesquisas sobre Ensino Tecnológico (EDUCITEC), 2 (4).

Plomin, R., DeFries, J. C., McClearn, G. E., \& McGuffin, P. (2010). Genética do Comportamento. (5a. ed.). São Paulo: Artmed..

Reisdoefer, D. N., Teixeira, E. M. M., \& Ramos, M. G. (Set./Dez. 2017). A influência da relação professor-estudante na aprendizagem discente: percepções de professores de Ciências e Matemática. Revista Exitus, 7 (3), 64-87.

Rohde, L. A., Barbosa, G., Tramontina, S., \& Polanczyk, G. (2000). Transtorno de déficit de atenção/hiperatividade. Revista Brasileira de Psiquiatria, 22 (II), 7-11.

Roldão, M. C. (Jan./Abr. 2007). Função docente: natureza e construção do conhecimento profissional. Revista Brasileira de Educação, 12 (34), 95.

Rosa, R., \& Cecílio, S. (2010). Educação e o uso pedagógico das tecnologias da informação e comunicação: a produção do conhecimento em análise. Educação em foco, 15 (1), 107- 126.

Rotta, N.T., Ohlweiler, L., \& Riesgo, R. S. dos. (2015). Transtornos da Aprendizagem: Abordagem Neurobiológica e Multidisciplinar. Artmed.

Schirmer, C. R., Fontoura, D. R., \& Nunes, M. L. (2004). Distúrbios da aquisição da linguagem e da aprendizagem. Jornal de Pediatria, 80,(2), 95-103.

Seidl-de-Moura, M. L., Ribas, A. F. P., Seabra, K. C., Pessoa, L. F., Nogueira, S. E., Mendes, D. M. L. F., Rocha, S. B., \& Vicente, C. C. (2007). Interações Mãe-Bebê de Um e Cinco Meses: Aspectos Afetivos, Complexidade e Sistemas Parentais Predominantes. Psicologia: Reflexão e Crítica, 21(1), 66-73.

Sevilha, B; \& Bussab, V. S. R. (Jan.-Mar. 2015). Interação Mãe-Criança e Desenvolvimento da Linguagem: A Influência da Depressão Pós-Parto. Psico, 46. 
Formação Continuada De Professores E O Uso De Vídeos-Relatos: Construção E Avaliação De Uma Intervenção

(1), 101-109.

Silva, E. M. A., \& Araújo, C. M. de. (2005). Reflexão em Paulo Freire: uma contribuição para a formação continuada de professores. V Colóquio Internacional Paulo Freire Recife, 19 a 22-setembro 2005.

Silva, M. (2000). Sala de Aula Interativa. Local: Editora Quartet.

Silva E Souza, M. M. G., Conceição, A. N., \& Pereira, A. A. (Jan.-Jun., 2018) Estudo sobre mudanças de atitudes sociais: contribuições a partir de cursos de capacitação. Revista Diálogos e Perspectivas em Educação Especial, 5 (1), 83-94.

Silveira, P. S. da, Martins, L. F., Soares. R. G., Gomide, H.P., \& Ronzani, T.M. (2011). Revisão sistemática da literatura sobre estigma social e alcoolismo. Estudos de Psicologia, 16 (2).

Sordi, M, R, L, de. (2005). A avaliação e seu potencial inovador nos processos de formação universitária: a visão dos professores de artes e letras. Revista de Educação PUC-Campinas, 19, 87-100.

Souza, I. M. A. de, \& Souza, L. V. A. de. (Jul./Dez. 2010). O uso da tecnologia como facilitadora da aprendizagem do estudante na escola. Revista Fórum Identidades, 8 (4), 127-29

Stein, M. B., \& Sareen, J. (2015). Generalized Anxiety Disorder. The New England Journal of Medicine, 373 (21), 2059-2068.

Tokumaru, R. S., Zortea, T. C., Howat-Rodrigues, A. B. C., \& Andrade, A. L. de. (Jan./Abr. 2011). Diferenças no investimento materno em função de variáveis socioambientais. Estudos de Psicologia, 16 (1), 49-55.

Treviso, V. C., \& Almeida, J. L. V. (2014). O conhecimento de Jean Piaget e a educação escolar. Cadernos de Educação: Ensino e Sociedade, 1 (1): 233-244.

Vascouto, H. D., Sbissa P., \& Takase, E. (2013). A utilização da meditação no contexto escolar: uma análise da literatura. Revista Caminhos, 4 (6), 87-106.

Walker, S. O.,\& Plomin, R. (2005). The Nature-Nurture Question: Teachers' perceptions of how genes and the environment influence educationally relevant behaviour. Educational Psychology, 25 (5), 509-516.

Wilkins, A.J., Smith, I.N., \& Jansons, J. E. (1991). Colorimeter for the intuitive manipulation of hue and saturation and its role in the study of perceptual distortion. Medical Research Council Applied Psychology Unit, 15 Chaucer Road: Cambridge. 


\section{Anexos}

\section{Anexo 1. Questionário}

Assinale apenas UMA das alternativas, e assinale apenas UM número nas escalas de 0 a 10 .

1. Você estudou aspectos da genética durante sua formação para

professor? ( ) Sim ( ) Não

2. Você tem algum conhecimento sobre influência genética em comportamentos humanos?

( ) $\operatorname{Sim}($ ) Não

3. Se sim, onde obteve esse conhecimento?
( ) Livros ( ) Jornais ( ) Revistas ( ) Documentários na TV
( ) Noticiários na TV ( ) Cinema ( ) Novela ( ) Amigos ( )
Internet ( ) Revistas científicas ( ) Cursos de capacitação ( )
Outros $\cdots \cdots \cdot$

Como você acha que as seguintes características listadas abaixo são influenciadas por genes e pelo ambiente.

4. Personalidade

( ) Somente genes

( ) Mais pelos genes do que pelo

ambiente

( ) Genes e ambiente, em partes

iguais

( ) Mais pelo ambiente do que pelos

genes

( ) Somente pelo ambiente

5. Considerando 0 para nenhuma influência e 10 para influência máxima, escolha e assinale um número nas escalas abaixo que corresponde melhor à importância que você atribui à influência GENÉTICA na PERSONALIDADE

Genética: $\underline{0-1-2-3-4-5-6-7-8-9-10}$

6. Considerando 0 para nenhuma influência e 10 para influência máxima, escolha e assinale um número nas escalas abaixo que corresponde melhor à importância que você atribui à influência AMBIENTAL na PERSONALIDADE

Ambiente: $\underline{0-1-2-3-4-5-6-7-8-9-10}$ 
Formação Continuada De Professores E O Uso De Vídeos-Relatos: Construção E Avaliação De Uma Intervenção

7. Inteligência (ou QI - Quociente Intelectual)

( ) Somente genes

( ) Mais pelos genes do que pelo ambiente

( ) Genes e ambiente, em partes iguais

( ) Mais pelo ambiente do que pelos

genes

( ) Somente pelo ambiente

8. Considerando 0 para nenhuma influência e 10 para influência máxima, escolha e assinale um número nas escalas abaixo que corresponde melhor à importância que você atribui à influência GENÉTICA na INTELIGÊNCIA

Genética: $\underline{0-1-2-3-4-5-6-7-8-9-10}$

9. Considerando 0 para nenhuma influência e 10 para influência máxima, escolha e assinale um número nas escalas abaixo que corresponde melhor à importância que você atribui à influência AMBIENTAL na INTELIGÊNCIA

Ambiente: $\underline{0-1-2-3-4-5-6-7-8-9-10}$

10. Dificuldades de aprendizagem

( ) Somente genes

( ) Mais pelos genes do que pelo

ambiente

( ) Genes e ambiente, em partes

iguais

( ) Mais pelo ambiente do que pelos

genes

( ) Somente pelo ambiente

11. Considerando 0 para nenhuma influência e 10 para influência máxima, escolha e assinale um número nas escalas abaixo que corresponde melhor à importância que você atribui à influência GENÉTICA nas DIFICULDADES DE APRENDIZAGEM

Genética: $\underline{0-1-2-3-4-5-6-7-8-9-10}$

12. Considerando 0 para nenhuma influência e 10 para influência máxima, escolha e assinale um número nas escalas abaixo que corresponde melhor à importância que você atribui à influência AMBIENTAL nas DIFICULDADES DE APRENDIZAGEM

Ambiente: $\underline{0-1-2-3-4-5-6-7-8-9-10}$ 
13. Problemas de comportamento

( ) Somente genes

( ) Mais pelos genes do que pelo

ambiente

( ) Genes e ambiente, em partes

iguais

( ) Mais pelo ambiente do que pelos

genes

( ) Somente pelo ambiente

14. Considerando 0 para nenhuma influência e 10 para influência máxima, escolha e assinale um número nas escalas abaixo que corresponde melhor à importância que você atribui à influência GENÉTICA nos PROBLEMAS DE COMPORTAMENTO

Genética: $\underline{0-1-2-3-4-5-6-7-8-9-10}$

15. Considerando 0 para nenhuma influência e 10 para influência máxima, escolha e assinale um número nas escalas abaixo que corresponde melhor à importância que você atribui à influência AMBIENTAL nos PROBLEMAS DE COMPORTAMENTO

Ambiente: 0 - 1-2-3-4-5-6-7-8-9-10

16. Doenças mentais

( ) Somente genes

( ) Mais pelos genes do que pelo

ambiente

( ) Genes e ambiente, em partes

iguais

( ) Mais pelo ambiente do que pelos

genes

( ) Somente pelo ambiente

17. Considerando 0 para nenhuma influência e 10 para influência máxima, escolha e assinale um número nas escalas abaixo que corresponde melhor à importância que você atribui à influência GENÉTICA nas DOENÇAS MENTAIS

Genética: $\underline{0-1-2-3-4-5-6-7-8-9-10}$

18. Considerando 0 para nenhuma influência e 10 para influência máxima, escolha e assinale um número nas escalas abaixo que corresponde melhor à importância que você atribui à influência AMBIENTAL nas DOENÇAS MENTAIS

Ambiente: $\underline{0-1-2-3-4-5-6-7-8-9-10}$

19. Sabendo-se que um aluno tem uma dificuldade de aprendizagem geneticamente influenciada, isto afetaria o seu método de instruir e acompanhar o aluno?

( ) Afetaria completamente

( ) Afetaria muito

( ) Afetaria em parte 
Formação Continuada De Professores E O Uso De Vídeos-Relatos: Construção E Avaliação De Uma Intervenção

( ) Afetaria um pouco

( ) Não afetaria

\section{Apêndices}

Apêndice A- Termo de Assentimento

TERMO DE ASSENTIMENTO LIVRE E ESCLARECIDO

Para crianças e adolescentes (maiores de 5 anos e menores de 18 anos) e para legalmente incapazes

Você está sendo convidado (a) a participar da pesquisa de mestrado: "Formação continuada de professores e o uso de vídeos-relatos: construção e avaliação de uma intervenção", coordenada pela Pesquisadora Monara Nelid Fortuna Vieira, sob orientação da Professora Dra. Fabiana Maris Versuti e co-orientação da Professora Dra. Patrícia Ferreira Monticelli.

Queremos criar vídeos com depoimentos de pessoas que tiveram problemas de aprendizagem, mas que melhoraram com o tempo por meio de alguma ação realizada. Você pode fazer o vídeo usando seu aparelho celular em sua casa mesmo (ou outro lugar que preferir) e nos enviar depois, ou então, pode pedir para a pesquisadora ir até o local que você está para gravar com uma máquina mais adequada para garantir a qualidade do vídeo.

Você participará da pesquisa se quiser e se sentir a vontade. Fica a seu critério aceitar, e se resolver desistir, não terá nenhum problema. Tudo isso, é considerado seguro, mas se ao realizar o vídeo, tiver algum desconforto, você pode entrar em contato com a responsável e desistir de participar, além do mais, um possível risco é o reconhecimento de sua imagem por pessoas que te assistiram. Destacamos que, com sua participação você poderá ajudar a Ciência no Brasil e outras pessoas que vivenciaram situações semelhantes a sua, por isso é importante sua participação.

Ao aceitar, deverá concordar com o uso de sua imagem e voz, pois seu vídeo será passado para alguns professores para ajudá-los no dia a dia com seus estudantes, e tomaremos todos os cuidados para evitar que sua filmagem seja assistida por outras pessoas que não estão relacionadas com a pesquisa. Os resultados poderão ser publicados 
em artigo científico, mas não aparecerá o seu nome e de ninguém que participou do estudo.

O telefone da pesquisadora é (14) 9998062541 , e poderá ligar para tirar qualquer dúvida que surgir. Pode também entrar em contato pelo e-mail: monara.biologia@gmail.com.

$\mathrm{Eu}$ RG. , aceito participar

desse estudo e declaro que entendi os pontos ruins e bons que podem acontecer; que posso desistir a qualquer momento; que a pesquisadora tirou minha (s) dúvida (s) e que conversou com meus pais; e que recebi uma cópia deste termo de assentimento livre e esclarecido.

Assinatura do menor

Assinatura da pesquisadora 
Formação Continuada De Professores E O Uso De Vídeos-Relatos: Construção E Avaliação De Uma Intervenção

\section{Apêndice B - Termo de Consentimento (filmagens) TERMO DE CONSENTIMENTO LIVRE E ESCLARECIDO}

Você está sendo convidado (a) a participar como voluntário (a) da pesquisa de mestrado intitulada: "Formação continuada de professores e o uso de vídeos-relatos: construção e avaliação de uma intervenção", que tem por objetivo desenvolver um banco de filmagens com relatos de indivíduos que foram diagnosticados com algum tipo de transtorno - de acordo com o Manual Diagnóstico e Estatístico de Transtornos Mentais - (DSM-5) - que afetou a aprendizagem, mas que teve seu desempenho melhorado, devido a uma intervenção tomada. Essa ferramenta terá aplicabilidade sugerida para a formação de professores com o intuito de alterar crenças que interferem no processo de "ensinar" e "aprender", rompendo possíveis estigmas que as pessoas carregam consigo acerca dos transtornos mentais.

Esta pesquisa faz parte do Mestrado da Bióloga Monara Nelid Fortuna Vieira, sob orientação da Professora Dra. Fabiana Maris Versuti e co-orientação da Professora Dra. Patrícia Ferreira Monticelli, do Departamento de Psicobiologia da Faculdade de Filosofia, Ciências e Letras de Ribeirão Preto, na Universidade de São Paulo (USP).

As filmagens serão utilizadas pelas pesquisadoras somente para fins acadêmicos, as quais terão todos os cuidados para que não ocorra a disseminação indevida dos vídeos. Com a pesquisa concluída, o banco de filmagens (já editado) poderá ser aplicado, e os dados e resultados obtidos poderão ser publicados em forma de artigo científico, mas, se assim for, garantimos o sigilo de sua identidade (nome) nesse momento, bem como a garantia do devido arquivamento dos documentos assinados pelos participantes.

Ao aceitar participar da pesquisa, terá que gravar um relato, e será autorizada a gravação conforme o local que você preferir, seguindo algumas instruções técnicas para que se produza um vídeo de qualidade. No entanto, é sugerido que a gravação ocorra no CETI-RP (Centro de Tecnologia da Informação de Ribeirão Preto), cujo é um estúdio localizado no campus da USP, apropriado para esse tipo de trabalho ou então, num lugar de senso comum com acompanhamento da pesquisadora. Estima-se um tempo de até 30 minutos para a gravação, mas os vídeos serão editados e apenas as falas mais relevantes permanecerão. Terá também que autorizar o uso de imagem e voz, que não terão proteção da identidade nesse momento. 
A pesquisa não é considerada invasiva e as responsáveis farão o possível para não serem gerados danos e nenhuma situação de desconforto, caso venham ocorrer, o participante tem o direito e a liberdade de retirar seu consentimento em qualquer fase, sem nenhum prejuízo a sua pessoa, independentemente do motivo. Seus possíveis riscos são vinculados somente a incômodo que as perguntas podem lhe causar e/ou constrangimento de se pôr diante a uma câmera, e possível reconhecimento de imagem pelas pessoas que terão acesso aos vídeos, ou seja, risco do não anonimato total. Será também garantida a qualidade do vídeo e a condução da pesquisa de maneira positiva acerca da questão tratada. O participante não receberá benefícios diretos, mas contribuirá com a Ciência no Brasil. Você não terá nenhuma despesa, prejuízo, premiação e remuneração por participar da pesquisa. Será desligado (a) aquele que realizar uma filmagem de baixa qualidade, implicando na compreensão do conteúdo; que não atender qualquer obrigatoriedade do processo; que forjar qualquer documentação; e que incompreenda a Língua Portuguesa, se for estrangeiro.

A pesquisadora se colocará disponível para quaisquer dúvidas e necessidades pelo telefone (14) 9998062541 e pelo e-mail: monara.biologia@usp.br ou monara.biologia@gmail.com. Você também poderá ter informações específicas sobre questões éticas dessa pesquisa diretamente no Comitê de Ética em Pesquisa da Faculdade de Filosofia, Ciências e Letras de Ribeirão Preto - FFCLRP-USP, no telefone (16) 33154811. Avenida Bandeirantes, 3900 - Bloco 1 - Sala 07 - 14040-901 - Ribeirão Preto - SP - Brasil, Fone: (16) 3315-4811, E-mail: coetp@ffclrp.usp.br

Após ser informado de todos os procedimentos da pesquisa, convido-o a assinar este Termo de Consentimento Livre e Esclarecido, para sua participação, que foi elaborado em duas vias, uma que ficará com o (a) senhor (a) e outra com a pesquisadora responsável. 
Formação Continuada De Professores E O Uso De Vídeos-Relatos: Construção E Avaliação De Uma Intervenção

$\mathrm{Eu}$, RG. , fui informado (a)

dos objetivos da pesquisa acima de maneira clara e detalhada e esclareci minhas dúvidas. Sei que em caso de dúvidas poderei contatar a pesquisadora responsável ou sua orientadora.

Autorizo o uso de imagem e voz para fins de pesquisa e conhecimento científico, sem quaisquer ônus e restrições.

Declaro que concordo com minha participação nesse estudo e que recebi uma cópia deste termo de consentimento livre e esclarecido.

Assinatura do participante

Assinatura da pesquisadora 


\section{Apêndice C- Termo de Consentimento (intervenção)}

\section{TERMO DE CONSENTIMENTO LIVRE E ESCLARECIDO}

Você está sendo convidado (a) a participar da pesquisa "Formação continuada de professores e o uso de vídeos-relatos: construção e avaliação de uma intervenção", que tem por objetivos: desenvolver um banco de filmagens com relatos verídicos de indivíduos que foram diagnosticados com algum tipo de transtorno, de acordo com o Manual Diagnóstico e Estatístico de Transtornos Mentais - (DSM-5), o qual influenciou de alguma forma na aprendizagem; e aplicar esses vídeos à comunidade docente, a fim de investigar opiniões sobre a influência genética e ambiental em comportamentos humanos e prevenir ou modificar possíveis estigmas advindos de tais opiniões. Esta pesquisa faz parte do Mestrado da Bióloga Monara Nelid Fortuna Vieira, sob orientação da Professora Dra. Fabiana Maris Versuti e co-orientação da Professora Dra. Patrícia Ferreira Monticelli, do Departamento de Psicobiologia da Faculdade de Filosofia, Ciências e Letras de Ribeirão Preto, na Universidade de São Paulo (USP).

O projeto foi concebido para que os voluntários participem de um curso virtual, com dinâmicas baseadas em: vídeos sobre casos reais, textos fundamentalmente científicos e fóruns reflexivos. Os participantes responderão três questionários em dois momentos, um juntamente com a entrega e concordância deste termo e outro após a conclusão das etapas do curso. Os questionários serão disponibilizados via plataforma virtual e terá tempo estimado para preenchimento de 20 minutos. As atividades serão realizadas em ambiente virtual e terá duração de seis semanas, com aproximadamente 60 minutos cada.

Solicitamos que, por meio deste termo, comprometa-se em não reproduzir o conteúdo disponibilizado na plataforma virtual em outros meios, como, por exemplo, em suas aulas ou em redes sociais, salvo sob autorização da pesquisadora responsável.

Você será esclarecido (a) sobre a pesquisa em qualquer aspecto que desejar. Pode ocorrer desconforto por ficar sentado durante a aplicação dos questionários ou da entrevista, mas orientações serão transmitidas pela pesquisadora com o intuito de evitar ou minimizar tais ocorrências. Há ainda, o constrangimento ao responder sobre opiniões pessoais, entretanto, é importante ressaltar que medidas de garantia, sigilo e orientações durante a todo o processo serão realizadas pela pesquisadora. 
Formação Continuada De Professores E O Uso De Vídeos-Relatos: Construção E Avaliação De Uma Intervenção

Os benefícios de sua participação estão ligados a oportunidade de conhecimento acerca da dinâmica de interação entre genes e ambientes na expressão de comportamentos humanos. Além disso, estará contribuindo com a Ciência no Brasil.

Os questionários serão tratados anonimamente. Sua presença neste trabalho é voluntária e a recusa em participar não irá ocasionar qualquer prejuízo. A participação no estudo não acarretará nenhum tipo de custo, premiação ou reembolso. Você estará livre para recusar, retirar seu consentimento ou interromper sua participação a qualquer momento que desejar, independentemente do motivo, sem ocasionar qualquer prejuízo a sua pessoa.

A pesquisadora se colocará disponível para quaisquer dúvidas e necessidades pelo telefone (14) 9998062541 e pelo e-mail: monara.biologia@usp.br ou monara.biologia@gmail.com. Você também poderá ter informações específicas sobre questões éticas dessa pesquisa diretamente no Comitê de Ética em Pesquisa da Faculdade de Filosofia, Ciências e Letras de Ribeirão Preto - FFCLRP-USP, no telefone (16) 33154811. Avenida Bandeirantes, 3900 - Bloco 01 - Sala 7 - Prédio da Administração FFCLRP/USP 14040-901 - Ribeirão Preto - SP - Brasil, Fone: (16) 3315-4811, E-mail: coetp@ffclrp.usp.br, ou ter maiores informações pelo EBAC - Laboratório de Etologia e Bioacústica do Programa de Pós- Graduação em Psicobiologia FFCLRP USP Avenida Bandeirantes, 3900 - Bloco 5 - FFCLRP/USP 14040-901 - Ribeirão Preto - SP - Brasil. Fone: (16) $3315-9093$.

Após ser informado de todos os procedimentos da pesquisa, convido-o a assinar este "Termo de Consentimento Livre e Esclarecido", que foi elaborado em duas vias, uma que ficará com o senhor (a) e outra com a pesquisadora responsável.

Assinatura participante 


\title{
Apêndice D- Termo de armazenamento de dados
}

\author{
TERMO DE ARMAZENAMENTO DE DADOS
}

Você está sendo convidado (a) a participar do projeto de pesquisa que tem como título: "Formação continuada de professores e o uso de vídeos-relatos: construção e avaliação de uma intervenção". Como mencionado no TCLE, esta pesquisa tem como objetivo principal testar a eficácia de uma intervenção para alteração de estigmas de professores em relação a seus estudantes, por meio da criação de vídeos com depoimentos de pessoas que tiveram problemas no processo educacional, mas que melhoraram por meio de alguma ação realizada.

Vale ressaltar que, apesar de ser utilizada a sua imagem, a orientadora responsável, bem como o grupo de pesquisa envolvido, garantirá o anonimato de seu nome. Informaremos ainda, a quem for assistir ao vídeo com sua imagem, que não os reproduza de forma alguma. Os participantes se comprometerão com isso no momento em que assinarem o termo de consentimento livre e esclarecido para participarem da pesquisa.

Todos os dados da presente pesquisa serão armazenados em um banco de dados digital, os quais não serão utilizados para fins comerciais e ficarão disponíveis para futuros estudos. Os dados armazenados no banco de dados permitirão que outros pesquisadores realizem novas pesquisas, ajudando a gerar novos conhecimentos. Mas, se uma nova pesquisa for realizada, mesmo que utilize esses mesmos dados, passará novamente pela aprovação do Comitê de Ética e Pesquisa. Lembrando que, você poderá retirar seu consentimento a qualquer momento do processo independentemente do motivo, não havendo qualquer prejuízo à sua pessoa.

Caso tenha alguma dúvida ou julgue necessário, poderá ter acesso aos dados que serão armazenados, bem como os resultados obtidos na pesquisa, uma vez que a orientadora e o grupo de pesquisa estarão a sua disposição para quaisquer esclarecimentos. Maiores informações podem ser solicitadas pelo e-mail: monara.biologia@usp.br. Sobre questões éticas dessa pesquisa poderá entrar em contato diretamente no Comitê de Ética em Pesquisa da Faculdade de Filosofia, Ciências e Letras de Ribeirão Preto - FFCLRP-USP, no telefone

(16) 3315-4811. Avenida Bandeirantes, 3900 - Bloco 01 - Sala 7 - Prédio da Administração FFCLRP/USP 14040-901 - Ribeirão Preto - SP - Brasil, Fone: (16) 
Formação Continuada De Professores E O Uso De Vídeos-Relatos: Construção E Avaliação De Uma Intervenção

3315-4811, E- mail: coetp@ffclrp.usp.br, ou ter maiores informações pelo EBAC Laboratório de Etologia e Bioacústica do Programa de Pós- Graduação em Psicobiologia FFCLRP USP AvenidaBandeirantes, 3900 - Bloco 5 - FFCLRP/USP 14040-901 - Ribeirão Preto - SP - Brasil. Fone: (16) 3315 - 9093.

Assinatura do participante

Assinatura da pesquisadora

Assinatura da orientadora 


\section{Apêndice E- . Tarefa de observação}

\section{$\underline{\text { Semana 1: }}$}

a. Quantos dos seus alunos (ou mesmo parentes) atualmente têm sintomas de TDA ou TDAH? (Não precisa ser diagnosticado, só ter os sintomas). E autismo?

b. Destes, quantos estão tendo acesso a estratégias diferenciadas de ensino? * Se não tiver alunos seus, observe alunos de outros professores ou converse com outros professores para realizar sua tarefa.

c. Diante do que vimos e discutimos, aplique uma estratégia diferenciada com estes alunos. Exemplos: ao invés de usar somente as habilidades escritas, solicitar habilidades orais ou desenhos; escolher junto com ele um novo lugar na sala; fazer um elogio; escutálo sobre o que o incomoda, entre outras coisas. Depois disso, relate se houve alguma reação/efeito, seja positivo ou negativo.

\section{Semana 2:}

a. Quantos dos seus alunos (ou mesmo parentes) atualmente têm sintomas de Síndrome de Irlen ou Hiperatividade? Discrimine. Destes, quantos estão tendo acesso a estratégias diferenciadas de ensino? *Se não tiver alunos seus, observe alunos de outros professores ou converse com outros professores para realizar sua tarefa.

b. Durante esta semana, dialogue com seus colegas de trabalho sobre a maneira que reagem aos alunos que possuem sintomas de déficit de atenção e hiperatividade. Relate.

c. Observe e converse com seus alunos sobre os sintomas da síndrome de Irlen. Tente compreender como eles se sentem em relação à leitura e visualização de textos, números e formas em geral. Relate sobre a observação e conversa. 
Formação Continuada De Professores E O Uso De Vídeos-Relatos: Construção E Avaliação De Uma Intervenção

d. Diante do que vimos e discutimos, aplique uma estratégia diferenciada com estes alunos (com Hiperatividade ou Síndrome de Irlen). Descreva-a e relate se houve algum efeito, seja ele positivo ou negativo.

\section{Semana 3:}

a. Na suspeita do aluno ter um destes distúrbios, acha que teria um olhar diferenciado para detectá-los? Faria o que para "concluir" algo ou para ajudá-lo?

b. Se for para escolher uma estratégia para melhorar a ansiedade do aluno ou para melhorar a condição de dislexia, qual seria? Aplique uma para cada distúrbio e relate como se fosse colocar em prática. Desafio: Colocar em prática.

c. Quantos dos seus alunos atualmente têm sintomas de ansiedade patológica ou de dislexia? Destes, quantos estão tendo acesso a estratégias específicas de ensino? Quais são essas estratégias? Os efeitos são positivos? 